\title{
RENAL FUNCTIONS IN THE COURSE OF THE NEPHROTIC SYNDROME IN CHILDREN 1,2
}

\author{
BY ERIKA BRUCK, MILTON RAPOPORT, AND MITCHELL I. RUBIN wITH THE \\ TECHNICAL ASSISTANCE OF MAJORIE SNIVELY, M. HELEN MCKAY, \\ ALVERNA BAUMLER, AND EDYTHE TAYLOR \\ (From the Departments of Pediatrics, School of Medicine, The University of Buffalo and The \\ University of Pennsylvania, Children's Hospital of Philadelphia, and the Statler \\ Research Laboratories of The Children's Hospital of Buffalo, N. Y.)
}

(Submitted for publication July 29, 1953; accepted October 29, 1953)

A clearer concept of the differential diagnosis of the nephrotic syndrome in children and its prognosis in individual cases is needed. As a contribution to the natural history of this syndrome, the functional capacity of the kidneys in the course of the disease was studied by means of clearance tests.

Renal clearance studies in children $(1-6)$ and adults $(7,8)$ with the nephrotic syndrome have been reported in the past. The conclusions of these reports have not been uniform, probably because patients in different phases of the nephrotic syndrome were selected or because the patients were not observed over a sufficient length of time for study.

In the present study the clearance tests were, wherever possible, repeated in individual patients at intervals over several years, until the outcome of the case appeared established. The results were correlated with the patients' clinical course and with other laboratory studies such as the analysis of the urine, including the Addis count, and of the chemical composition of the blood serum.

\section{CLINICAL MATERIAL}

A total of 45 patients were studied. Thirty-three of these children were seen at the Children's Hospital of Buffalo and 12 at the Children's Hospital of Philadelphia.

Forty-three patients had, at some time in their course, the nephrotic syndrome defined as edema, massive albuminuria, hypoalbuminemia, and hypercholesterolemia.

\footnotetext{
1 Part of this material was presented as an exhibit at the Fifth International Pediatric Congress in New York in 1947, and some of the data were included in the Presidential address before the Society for Pediatric Research in the same year.

2 We should like to extend our thanks to the Sharp and Dohme Company of Glenolden, Pa., for generously supplying us with mannitol and sodium para-amino-hippurate used in these studies.
}

The remaining two patients had laboratory signs of the nephrotic syndrome but no edema during one and three years, respectively, of observation. Glomerulonephritis was diagnosed when, in addition to the nephrotic syndrome, there was azotemia, considerable or persistent hematuria as determined by the Addis count, or persistent hypertension. Transient microscopic hematuria or transient elevation of the blood pressure during an intercurrent illness was not interpreted in this manner. In some cases the diagnosis was changed from presumed "lipoid nephrosis" to "nephrotic syndrome with nephritis" or vice versa in the light of later findings; in three instances the diagnosis was changed as the result of post mortem findings.

Twenty-four patients between the ages of 8 months and 15 years had the nephrotic syndrome with glomerulonephritis. Fourteen of these patients are known to be dead at the time of this writing, five are known to have active disease and the outcome of the remaining five is not known (three of these are alive). Nineteen of these 24 patients were followed for periods varying from one to ten years.

Twenty-one patients were diagnosed as having presumed "lipoid nephrosis" since they did not exhibit the signs mentioned above as indicative of glomerulonephritis. It must be admitted that some of the children in this group were not followed for sufficiently long periods to permit a final evaluation. Eleven of these patients apparently have recovered completely. Two still have albuminuria but are otherwise well. Three children died of complications and one of an unknown cause at home, and four children have been lost from observation.

\section{METHODS}

Glomerular filtration rate (GFR) was determined as mannitol clearance, in a few cases as inulin clearance, using the single injection technique.

The urea clearance was determined simultaneously with the glomerular filtration rate.

Effective renal plasma flow (RPF) was determined as clearance of sodium para-amino-hippurate at low plasma levels which were maintained by a continuous intravenous infusion; tubular excretory capacity for para-amino-hippurate ( $\mathrm{TmPAH}$ ) was calculated from the excretion of PAH at high plasma levels and the glomerular filtra- 
TABLE I

Clinical and laboratory data on patients with the nephrotic symdrome with glomerulonephritis * $f$

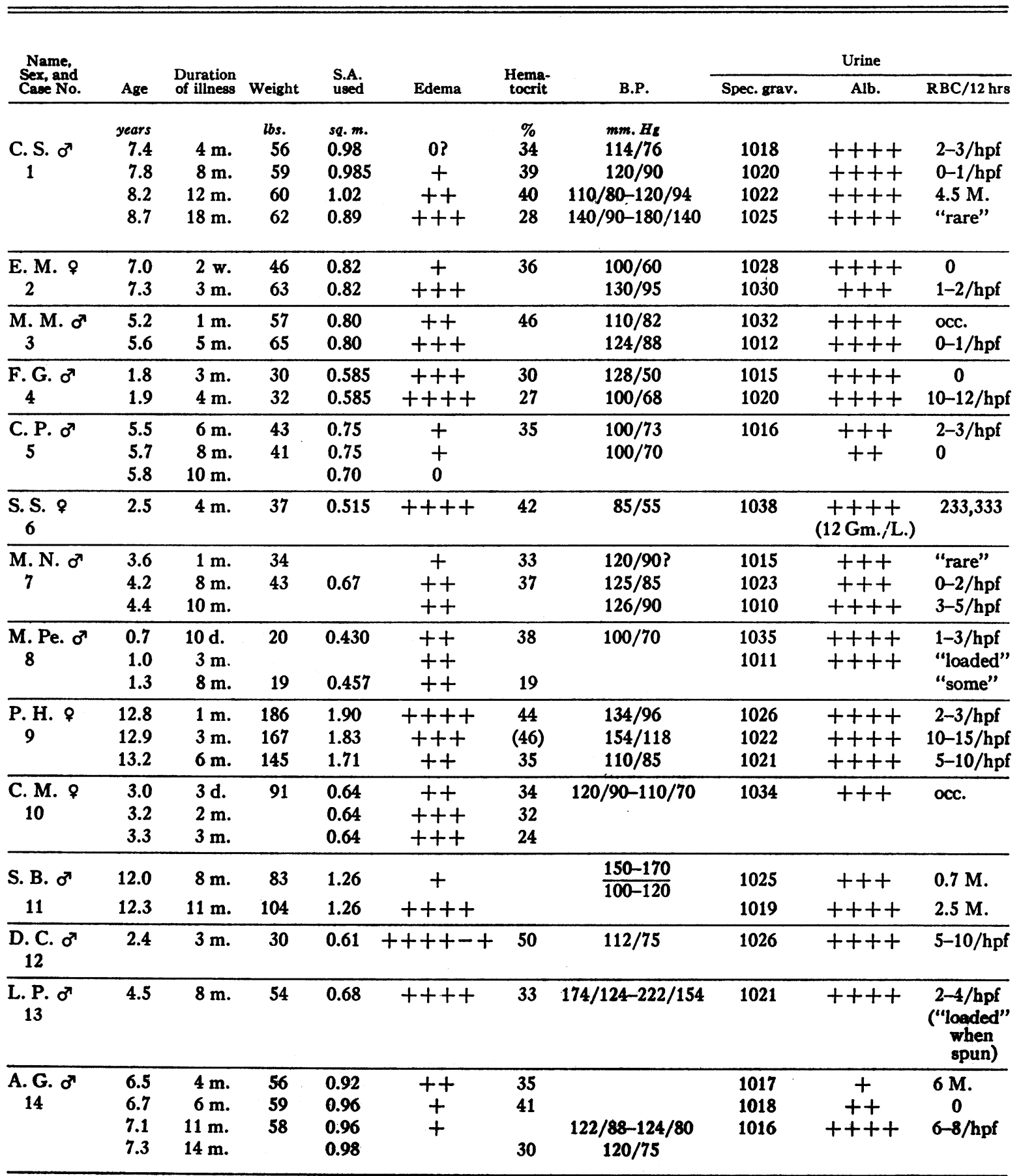

- See Appendix B for remarks and ctinical observations on these patients.

$\uparrow$ The fgures given for the renal functional data are averages of values obtained in three or more periods. The values are corrected to a surface area of $1.73 \mathrm{sq} . \mathrm{m}$. 
TABLE I-Continued

Clinical and laboratory data on patients with the nephrotic syndrome with glomerulonephritis

\begin{tabular}{|c|c|c|c|c|c|c|c|c|c|c|c|}
\hline \multicolumn{4}{|c|}{ Blood serum } & \multirow[b]{2}{*}{ GFR } & \multirow[b]{2}{*}{$\mathrm{Cu}$} & \multirow[b]{2}{*}{$\mathbf{R P F}$} & \multirow[b]{2}{*}{ FF } & \multirow[b]{2}{*}{ TmPAH } & \multirow[b]{2}{*}{$\underset{\text { TmPAH }}{\text { GFR/ }}$} & \multirow[b]{2}{*}{$\underset{\text { TmPAH }}{R \text { RPF/ }}$} & \multirow[b]{2}{*}{$\begin{array}{l}\text { Range of } \\
\text { U.F. }\end{array}$} \\
\hline $\begin{array}{l}\text { Urea-N, } \\
\text { or } \\
\text { (NPN) }\end{array}$ & T.P. & Alb. & $\begin{array}{c}\text { Choles- } \\
\text { terol }\end{array}$ & & & & & & & & \\
\hline $\begin{array}{c}m g . \% \\
9.8\end{array}$ & $\begin{array}{c}G m . \% \\
3.1\end{array}$ & $\begin{array}{c}G m . \% \\
1.7\end{array}$ & $\begin{array}{c}\text { mg. \% } \\
790\end{array}$ & \multicolumn{3}{|c|}{$c c . / \min . / 1.73$ sq. $m}$. & 0.168 & \multicolumn{2}{|l|}{$\begin{array}{l}\text { mg./min./ } \\
1.73 \mathrm{sq.} \mathrm{m} .\end{array}$} & 8.3 & \multirow[t]{4}{*}{$\begin{array}{c}c c . / \min . / \\
1.73 \text { sq. } m . \\
1.45-3.16\end{array}$} \\
\hline 17.8 & 3.9 & 1.8 & 680 & 81 & 51.5 & 680 & 0.119 & 107 & 0.76 & 6.4 & \\
\hline 21.7 & 4.7 & 3.3 & & 53 I & 14 & 412 & 0.129 & $35(?)$ & 1.51 & 11.8 & \\
\hline 25.1 & 4.4 & 1.3 & 1000 & $\begin{array}{l}23.4 \mathrm{M} \\
22.8 \mathrm{I}\end{array}$ & 18.5 & 224 & 0.102 & $9.7^{\circ}$ & 2.35 & 23.1 & \\
\hline 11.7 & \multirow[t]{2}{*}{5.3} & & 627 & \multirow{2}{*}{\multicolumn{2}{|c|}{$\begin{array}{r}108 \\
76 \\
\end{array}$}} & 911 & 0.119 & \multirow[t]{2}{*}{78.5} & 1.38 & \multirow[t]{2}{*}{11.6} & \\
\hline 17 & & & 1425 & & & $437 ?$ & $0.175 ?$ & & & & \\
\hline 9.2 & 4.9 & 2.1 & 1040 & $95 \mathrm{M}$ & 65 & 773 & 0.123 & 89 & 1.07 & 8.8 & $0.98-1.71$ \\
\hline 32.3 & $(4.6)$ & $(1.6)$ & 960 & 75 I & 28 & 719 & 0.104 & 81 & 0.93 & 8.9 & $0.46-3.04$ \\
\hline 24.6 & 3.8 & 1.5 & 780 & 63 I & 17.5 & 498 & 0.126 & 23 & 2.74 & 21.7 & $0.67-2.52$ \\
\hline 22.8 & 4.0 & 2.0 & 660 & 65 I & 27 & 452 & 0.144 & 32 & 2.04 & 14.1 & $0.58-2.77$ \\
\hline \multirow[t]{3}{*}{21.2} & \multirow{3}{*}{$\begin{array}{l}6.0 \\
6.2\end{array}$} & \multirow{3}{*}{$\begin{array}{l}1.7 \\
4.0\end{array}$} & \multirow{3}{*}{$\begin{array}{l}512 \\
640\end{array}$} & \multirow{3}{*}{$\begin{array}{r}49 \\
111 \\
158\end{array}$} & & 565 & 0.090 & \multirow{3}{*}{$\begin{array}{l}56.4 \\
139 \\
173.5\end{array}$} & 1.04 & \multirow{3}{*}{$\begin{array}{c}10.0 \\
4.67 \\
5.9\end{array}$} & \\
\hline & & & & & 41 & 647 & 0.172 & & 0.80 & & $1.98-7.61$ \\
\hline & & & & & 78 & 1025 & 0.154 & & 0.91 & & \\
\hline 10.8 & 3.9 & 1.6 & 777 & 111 & 60 & 768 & 0.145 & 134 & 0.83 & 5.7 & $1.04-4.77$ \\
\hline (22) & 4.2 & 1.9 & 440 & & & & & & & & \\
\hline 12.0 & 4.0 & 0.9 & 860 & 56 & 37 & 870 & 0.065 & 63 & 0.90 & 13.8 & $9.78-3.81$ \\
\hline (44) & $(3.9)$ & $(1.3)$ & & & & & & & & & \\
\hline 23.6 & 2.3 & 0.8 & 407 & 38 & 19 & 371 & 0.102 & 41.5 & 0.91 & 8.9 & $0.54-2.26$ \\
\hline 32.5 & & & & & & & & & & & \\
\hline 55.8 & & & & 14.3 & 7.4 & $56 ?$ & $0.254 ?$ & 5.4 & 2.65 & & $1.35-1.76$ \\
\hline 10.9 & 3.9 & 1.8 & 527 & 91 & 62 & 798 & 0.114 & 101 & 0.90 & 7.9 & $2.21-4.44$ \\
\hline 14.8 & 4.1 & 1.2 & 880 & 68 & 40 & 394 & 0.173 & 33 & 2.06 & 12.0 & $1.97-3.18$ \\
\hline 15.0 & 2.5 & 0.7 & 650 & 49 & 35 & & & 39 & 1.26 & & $3.34-4.41$ \\
\hline 23.5 & 4.2 & 1.7 & 704 & 67 & 38 & $774 ?$ & $0.087 ?$ & 98.5 & 0.68 & $7.9 ?$ & $0.52-3.37$ \\
\hline & & & & 46 & 10 & 1080 & 0.043 & 82 & 0.57 & 13.2 & $0.33-0.47$ \\
\hline & & & & 14 & & 769 & 0.019 & 101.5 & 0.14 & 7.6 & \\
\hline 14.6 & 5.2 & 2.7 & 258 & 39 & $32 ?$ & & & & & & $2.12-9.9$ \\
\hline & 5.0 & & 644 & 22 & & $132 ?$ & $0.167 ?$ & 8 & 2.4 & & $1.67-3.08$ \\
\hline 32.3 & 4.2 & 0.9 & 710 & 19.5 & 17 & 269 & 0.073 & 40 & 0.49 & 6.8 & $0.90-1.94$ \\
\hline 28.4 & 4.0 & 0.8 & 453 & 11.5 & 7.0 & $36 ?$ & & 5.8 & 1.98 & & $0.66-1.63$ \\
\hline 16 & 7.1 & 3.3 & 232 & 122 & & & & & & & \\
\hline 16 & 5.0 & 1.7 & 317 & 90 & 49 & 785 & 0.115 & $>118$ & & & $3.25-5.85$ \\
\hline 10.1 & 5.2 & 3.0 & 304 & 141 & 58 & 1333 & 0.106 & 124 & 1.14 & 10.7 & \\
\hline & & & & 181 & & & & 147 & 1.23 & & \\
\hline
\end{tabular}




\begin{tabular}{|c|c|c|c|c|c|c|c|c|c|c|}
\hline \multirow{2}{*}{$\begin{array}{l}\text { Name, } \\
\text { Sex, and } \\
\text { Case No. }\end{array}$} & \multirow[b]{2}{*}{ Age } & \multirow{2}{*}{$\begin{array}{l}\text { Duration } \\
\text { of illness }\end{array}$} & \multirow{2}{*}{ Weight } & \multirow{2}{*}{$\begin{array}{l}\text { S.A. } \\
\text { used }\end{array}$} & \multirow[b]{2}{*}{ Edema } & \multirow{2}{*}{$\begin{array}{c}\text { Hema- } \\
\text { tocrit }\end{array}$} & \multirow[b]{2}{*}{ B.P. } & \multicolumn{3}{|c|}{ Urine } \\
\hline & & & & & & & & Spec. grav. & Alb. & $\mathrm{RBC} / 12 \mathrm{hrs}$ \\
\hline \multirow[t]{12}{*}{$\underset{15}{\text { M. C. } \sigma^{7}}$} & $\begin{array}{r}\text { years } \\
5.9\end{array}$ & $1 \mathrm{w}$ & $\begin{array}{l}\text { lbs. } \\
36\end{array}$ & $s q . m$. & 0 & $\begin{array}{l}\% \\
31\end{array}$ & $\begin{array}{l}m m . H g \\
120 / 90\end{array}$ & 1021 & ++++ & $\begin{array}{l}\text { grossly } \\
\text { bloody }\end{array}$ \\
\hline & 6.7 & $9 \mathrm{~m}$ & & & 0 & $38-33$ & $110 / 80$ & 1020 & +++ & $40-2 / \mathrm{hpf}$ \\
\hline & 8.7 & $33 \mathrm{~m}$. & 49 & 0.88 & trace & & $100 / 75$ & 1021 & ++++ & $40 \mathrm{M}$ \\
\hline & 8.8 & $34 \mathrm{~m}$. & 51 & 0.80 & 0 & 41 & $122 / 80$ & 1007 & $+t+t$ & $4-6 / \mathrm{hpf}$ \\
\hline & 9.6 & $45 \mathrm{~m}$. & 55 & 0.97 & 0 & 44 & $124 / 75$ & 1025 & $++t+$ & 0 \\
\hline & 9.8 & $47 \mathrm{~m}$. & 55 & 0.97 & 0 & 43 & $106 / 70$ & 1020 & $++t+$ & $49 \mathrm{M}$. \\
\hline & 10.7 & $58 \mathrm{~m}$. & 60 & 1.02 & 0 & 46 & $118 / 84$ & 1011 & ++++ & 54 M. \\
\hline & 11.3 & $66 \mathrm{~m}$. & & & + & 40 & $118 / 68$ & 1018 & $+++t$ & $72 \mathrm{M}$. \\
\hline & 11.7 & $69 \mathrm{~m}$. & 66 & 1.09 & + & 40 & $120 / 80$ & 1005 & $++t+$ & $54 \mathrm{M}$ \\
\hline & 12.6 & $80 \mathrm{~m}$. & 72 & 1.15 & + & 36.5 & $128 / 96$ & 1015 & $+t+t$ & $1-6 / \mathrm{hpf}$ \\
\hline & 12.8 & $83 \mathrm{~m}$. & 72 & 1.17 & + & 35 & $132 / 94$ & & $+t+$ & $1-2 / \mathrm{hpf}$ \\
\hline & 13.2 & $87 \mathrm{~m}$. & 71 & & trace & & $144 / 110$ & 1012 & +++ & $1-2 / \mathrm{hpf}$ \\
\hline \multirow{4}{*}{ J. J. } & 1.3 & $1 \mathrm{w}$. & 31 & 0.623 & +++ & 40 & $96 / 56-132 / 70 ?$ & 1027 & $+++t$ & $0-1 / \mathrm{hpf}$ \\
\hline & 1.5 & $2 \mathrm{~m}$ & 35 & 0.623 & $++t+$ & 35 & & 1030 & ++++ & $8-10 / \mathrm{hpf}$ \\
\hline & 1.9 & $7 \mathrm{~m}$ & 30 & 0.603 & 0 & 43 & $108 / 64$ & 1022 & $++t$ & \\
\hline & 2.8 & $17 \mathrm{~m}$. & 35 & 0.70 & 0 & 40 & $118 / 64$ & 1028 & trace to + & 90,000 \\
\hline \multirow[t]{3}{*}{ J. E. ๙ } & 4.2 & $6 \mathrm{~m}$. & & & $+t+$ & 42 & $120 / 80-90 / 70$ & 1036 & $+t+t$ & $\begin{array}{l}\text { gross } \\
\text { hematuria }\end{array}$ \\
\hline & 9.1 & $5.5 \mathrm{y}$. & 57 & 0.99 & 0 & & $120 / 70$ & 1023 & 0 & 24,000 \\
\hline & 12.3 & $8.5 \mathrm{y}$. & 75 & 1.21 & 0 & & $122 / 70$ & 1025 & +++ & 0 \\
\hline J. B. $0^{7}$ & 12.4 & $1 \mathrm{~m} . ?$ & 63 & & \pm & 41 & $124 / 60$ & 1011 & $+++t$ & $3-5 / \mathrm{hpf}$ \\
\hline 18 & 13.3 & $12 \mathrm{~m}$ & 74 & 1.17 & 0 & 39 & $110 / 70$ & 1020 & & $2.3 \mathrm{M}$ \\
\hline \multirow{3}{*}{$\begin{array}{l}\text { R. T. } \\
19\end{array}$} & 10.0 & $?$ & 70 & 1.09 & 0 & 41 & $124 / 80$ & 1028 & ++ & $1.07 \mathrm{M}$ \\
\hline & 10.8 & $?$ & 79 & 1.17 & 0 & 38 & $110 / 66$ & 1012 & $+t+$ & $8.7 \mathrm{M}$. \\
\hline & 12.3 & $?$ & & & $\mathbf{0}$ & 44 & $122 / 92-120 / 80$ & 1026 & $++t$ & $5.7 \mathrm{M}$. \\
\hline \multirow{11}{*}{$\begin{array}{l}\text { C. A. }{ }^{2} \\
\end{array}$} & 7.8 & $3 \mathrm{~m}$. & 53 & 0.94 & + & 39 & $134 / 70$ & 1015 & & $?$ \\
\hline & 7.9 & $4 \mathrm{~m}$ & 48 & 0.88 & 0 & & $140 / 92$ & 1005 & ++++ & $1.7 \mathrm{M}$. \\
\hline & 8.1 & $6 \mathrm{~m}$ & 53 & & trace & & $108 / 70$ & & & \\
\hline & 8.2 & $7 \mathrm{~m}$ & & 0.94 & + & 23 & $125 / 40$ & 1016 & ++++ & $40-50 / \mathrm{hpf}$ \\
\hline & 8.3 & $7.5 \mathrm{~m}$ & 49 & 0.92 & 0 & 41 & $124 / 80$ & 1026 & $+t+t$ & $4.8 \mathrm{M}$ \\
\hline & 8.8 & $15 \mathrm{~m}$. & 56 & 0.98 & 0 & 31 & $108 / 50$ & 1025 & $+t+t$ & $5.4 \mathrm{M}$ \\
\hline & 9.8 & $27 \mathrm{~m}$. & & & 0 & & $130 / 78$ & 1010 & ++ & 0 \\
\hline & 10.2 & $31 \mathrm{~m}$. & & & 0 & & $120 / 68$ & 1020 & $+t+t$ & 4.7 M. \\
\hline & 10.5 & $35 \mathrm{~m}$. & 77 & 1.20 & 0 & 35 & $122 / 66$ & 1015 & $++t+$ & \\
\hline & 11.4 & $46 \mathrm{~m}$. & 93 & 1.35 & 0 & 31 & & & & \\
\hline & 13.8 & $74 \mathrm{~m}$. & 116 & & 0 & & $134 / 80$ & & +++ & "rare" \\
\hline G. H. $\sigma^{7}$ & 3 & 3 w. & & & $+t+$ & & $130 / 98$ & 1040 & $+t+t$ & 0 \\
\hline 21 & 10 & $7 \mathrm{y}$. & 78 & 1.20 & 0 & 49 & $130 / 90$ & 1030 & +++ & 90,657 \\
\hline A. P. $\%$ & 1.8 & $?$ & 22 & 0.490 & 0 & 36 & $125 / 82$ & 1020 & $+t+t$ & $3-5 / \mathrm{hpf}$ \\
\hline \multirow[t]{7}{*}{22} & 1.9 & $1 \mathrm{~m}$ & 22 & 0.500 & 0 & 33 & $126 / 76$ & 1009 & $+++t$ & 0 \\
\hline & 2.0 & $2 \mathrm{~m}$ & 23 & 0.511 & 0 & 44 & $125 / 80$ & 1010 & $++t$ & 0 \\
\hline & 2.4 & $7 \mathrm{~m}$ & 28 & 0.583 & 0 & 40 & $126, ' 80$ & 1021 & $+++t$ & 0 \\
\hline & 3.0 & $15 \mathrm{~m}$. & 31 & 0.63 & 0 & 43 & $120 / 70$ & 1009 & $+t+t$ & $0-1 / \mathrm{hpf}$ \\
\hline & 3.8 & $24 \mathrm{~m}$ & 33 & 0.66 & 0 & 39 & $114 / 66$ & 1015 & ++++ & 0 \\
\hline & 5.4 & $43 \mathrm{~m}$. & 41 & 0.74 & trace & 40 & $140 / 90$ & 1024 & $+t+t$ & $1.52 \mathrm{M}$ \\
\hline & 6.5 & $56 \mathrm{~m}$. & 41 & 0.75 & 0 & & $172 / 116$ & 1014 & ++++ & $8-10 / \mathrm{hpf}$ \\
\hline \multirow[t]{2}{*}{$\underset{23}{\text { T.M. } \sigma^{7}}$} & 13 & $4 \mathrm{y}$. & 81 & 1.28 & 0 & 27 & $146 / 105$ & $\begin{array}{c}1008 \\
\text { (Addis ct.) }\end{array}$ & +++ & $6 \mathrm{M}$. \\
\hline & 14 & $5 \mathrm{y}$. & 97 & 1.39 & 0 & 21 & $166 / 114$ & $\begin{array}{c}1017 \\
\text { (Addis ct.) }\end{array}$ & $\begin{array}{c}0.72 \mathrm{Gm} . / \\
12 \mathrm{hr} .\end{array}$ & $13.2 \mathrm{M}$ \\
\hline D. P. ه & $\begin{array}{l}12.7 \\
13.1\end{array}$ & $\begin{array}{l}7 \mathrm{y} . \\
8 \mathrm{y} .\end{array}$ & 71 & 1.12 & $\begin{array}{l}+ \\
+\end{array}$ & $\begin{array}{l}30 \\
22\end{array}$ & $\begin{array}{l}164 / 130 \\
170 / 110\end{array}$ & $\begin{array}{l}1012 \\
1010\end{array}$ & $\begin{array}{l}++++ \\
++++\end{array}$ & $\begin{array}{c}0 \text { to many } \\
2-6 / \mathrm{hpf}\end{array}$ \\
\hline
\end{tabular}




\begin{tabular}{|c|c|c|c|c|c|c|c|c|c|c|c|}
\hline \multicolumn{4}{|c|}{ Blood serum } & \multirow[b]{2}{*}{ GFR } & \multirow[b]{2}{*}{$\mathrm{Cu}$} & \multirow[b]{2}{*}{ RPF } & \multirow[b]{2}{*}{ FF } & \multirow[b]{2}{*}{ TmPAH } & \multirow[b]{2}{*}{$\begin{array}{c}\text { GFR/ } \\
\text { TmPAH }\end{array}$} & \multirow[b]{2}{*}{$\begin{array}{c}\text { RPF/ } \\
\text { TmPAH }\end{array}$} & \multirow[b]{2}{*}{$\begin{array}{c}\text { Range of } \\
\text { U.F. }\end{array}$} \\
\hline $\begin{array}{l}\text { Urea-N, } \\
\text { or } \\
\text { (NPN) }\end{array}$ & T.P. & Alb. & $\begin{array}{c}\text { Choles- } \\
\text { terol }\end{array}$ & & & & & & & & \\
\hline $\begin{array}{c}\text { mg. } \% \\
(45)\end{array}$ & $\begin{array}{c}G m . \% \\
7.0\end{array}$ & $\begin{array}{c}G m . \% \\
4.7\end{array}$ & $m g . \%$ & \multicolumn{3}{|c|}{$c c . / \min . / 1.73$ sq. m. } & & $\begin{array}{l}\text { mg. } / \text { min. } / \\
1.73 \mathrm{sq} . \mathrm{m} .\end{array}$ & & & $\begin{array}{l}c c . / \mathrm{min} . / \\
1.73 \mathrm{sq} . \mathrm{m} .\end{array}$ \\
\hline (27) & 4.3 & 2.5 & 166 & & & & & & & & \\
\hline 15.7 & 6.0 & 2.4 & 352 & 96 & 38 & 835 & 0.103 & 133 & 0.65 & 6.3 & $0.60-6.88$ \\
\hline 8.1 & 5.8 & 3.5 & & 169 & 112 & 1137 & 0.154 & 128 & 1.37 & 8.9 & $4.60-12.23$ \\
\hline 7.1 & & & & 180 & 106 & 802 & 0.224 & & & & $3.28-8.00$ \\
\hline 8.1 & 5.1 & 2.5 & 378 & 176.5 & 100 & 1023 & 0.173 & 59.5 & 2.96 & 17.2 & $3.52-5.56$ \\
\hline 8.8 & 4.9 & & & 152 & 63.5 & 761 & 0.200 & 43 & 3.54 & 17.2 & $2.48-4.26$ \\
\hline (44) & 4.3 & 2.5 & 550 & & & & & & & & \\
\hline 10.9 & 3.8 & 0.6 & 656 & 83 & 60 & 673 & 0.123 & 78 & 1.06 & 8.6 & $2.95-4.50$ \\
\hline 9.6 & 2.3 & 0.7 & 580 & $\begin{array}{l}41 \mathrm{M} \\
44 \mathrm{I}\end{array}$ & 28.5 & 415 & $\begin{array}{l}0.099 \mathrm{M} \\
0.106 \mathrm{I}\end{array}$ & 38 & $\begin{array}{l}1.08 \mathrm{M} \\
1.16 \mathrm{I}\end{array}$ & 10.9 & $2.10-4.70$ \\
\hline 12.0 & 4.3 & 1.3 & 525 & $45 \mathrm{M}$ & 28 & 296 & 0.152 & 19.5 & 2.3 & 15.2 & $2.17-3.34$ \\
\hline 15.8 & 4.4 & 1.8 & 622 & $\begin{array}{ll}25.5 \mathrm{M} \\
30 \mathrm{I} \\
\end{array}$ & 20.5 & $163 ?$ & $\begin{array}{l}<0.156 \mathrm{M} \\
<0.184 \mathrm{I} \\
\end{array}$ & & & & $1.73-3.79$ \\
\hline 16.5 & 3.3 & 1.7 & 302 & 77 & 41 & 404 & 0.191 & 53 & 1.45 & 7.6 & $1.58-2.93$ \\
\hline 25 & 4.7 & 0.8 & 860 & 39 & 11.7 & 425 & 0.092 & 34 & 1.15 & 12.5 & $0.81-1.91$ \\
\hline 13.3 & 5.3 & 3.1 & 296 & 135 & 103 & 665 & 0.203 & 113 & 1.20 & 5.9 & $1.88-3.56$ \\
\hline 16.3 & 5.4 & 4.0 & 198 & 94 & 52 & 643 & 0.149 & 92 & 1.04 & 7.0 & $1.91-3.74$ \\
\hline (22) & 3.1 & 0.6 & 107 & & & & & & & & \\
\hline 11.5 & 6.5 & 4.6 & 119 & 121 & 71.5 & 457 & 0.255 & 81 & 1.49 & 5.6 & $1.80-5.35$ \\
\hline 11.1 & 4.0 & 2.1 & $(440)$ & 100 & 64 & 551 & 0.181 & 77 & 1.30 & 7.15 & $1.77-3.38$ \\
\hline (30) & 6.3 & & & & & & & & & & \\
\hline 10.0 & 6.1 & 3.9 & & 121 & 71 & 766 & 0.158 & 163 & 0.74 & 4.7 & $1.64-5.28$ \\
\hline 18.2 & 5.6 & 3.5 & 288 & 93.5 & 53 & 740 & 0.126 & 65 & 1.44 & 11.4 & $3.07-4.94$ \\
\hline 16.2 & 7.4 & 5.0 & 187 & 91 & 60 & 634 & 0.143 & 79.5 & 1.14 & 8.0 & $3.84-5.67$ \\
\hline 10 & 6.6 & 4.5 & 277 & & & & & & & & \\
\hline 14 & 4.6 & 1.7 & 455 & 65.5 & 49 & 486 & 0.135 & 35 & 1.90 & 13.9 & $1.51-2.89$ \\
\hline $\begin{array}{l}16.5 \\
(44)\end{array}$ & 5.8 & 2.7 & 338 & 72 & 47 & 674 & 0.107 & 62 & 1.16 & 10.9 & $2.01-4.45$ \\
\hline 44.2 & 4.6 & 2.3 & 272 & 45 & 15 & 363 & 0.124 & 18 & 2.46 & 19.8 & $1.05-2.26$ \\
\hline 15.5 & 7.0 & 4.3 & & 82 & 43 & 611 & 0.134 & & & & $1.61-1.71$ \\
\hline 16.7 & 6.8 & 4.5 & 245 & 95 & 55 & 696 & 0.136 & 95 & 1.00 & 7.3 & $2.69-4.54$ \\
\hline & & & 294 & & & & & & & & \\
\hline 19.0 & 5.4 & 4.2 & 260 & 85 & 48 & 625 & 0.136 & 99 & 0.86 & 6.3 & $3.42-5.82$ \\
\hline 13.7 & & & & 86 & 47 & 642 & 0.134 & 93 & 0.92 & 6.9 & \\
\hline 19.9 & 5.4 & 3.0 & 120 & $68 \mathrm{I}$ & 34 & 656 & 0.104 & 81 & 0.84 & 8.1 & $1.77-8.01$ \\
\hline (27) & 4.2 & 1.8 & & & & & & & & & \\
\hline 10.6 & 5.5 & 4.0 & & 90 & 51 & 576 & 0.151 & 102 & 0.84 & 5.5 & $1.30-3.57$ \\
\hline 18.6 & 5.3 & 2.3 & 145 & 66 & 55 & 444 & 0.149 & 72.5 & 0.91 & 6.1 & $3.33-6.45$ \\
\hline 10.2 & 5.1 & 2.3 & 320 & 92 & 76 & 530 & 0.176 & 73 & 1.28 & 7.3 & $2.46-3.90$ \\
\hline 23.9 & 5.4 & & 328 & 81 & 42.5 & 294 & 0.276 & 67 & 1.21 & 4.4 & $2.07-3.73$ \\
\hline 18.9 & 5.5 & 3.0 & 420 & 69 & 46 & 322 & 0.215 & 61 & 1.13 & 5.3 & $3.21-3.65$ \\
\hline 14.7 & 5.2 & 2.0 & 515 & 67.5 & 47 & 385 & 0.177 & 59.5 & 1.13 & 6.5 & $2.54-4.08$ \\
\hline 19.2 & 5.4 & 2.4 & 590 & 69 & 38 & 369 & 0.187 & 57 & 1.21 & 6.5 & $2.03-3.41$ \\
\hline 28.5 & 5.4 & 1.6 & 272 & $36 \mathrm{I}=\mathrm{M}$ & 29 & 213 & 0.168 & 44.5 & 0.80 & 4.8 & $2.04-3.91$ \\
\hline \multirow[t]{3}{*}{28} & 5.0 & 2.3 & 338 & $26.5 \mathrm{I}$ & & & & 4.2 & 6.3 & & $1.69-2.10$ \\
\hline & & & & 35 & & & & & & & $5.72-9.96$ \\
\hline & 6.2 & 4.6 & 288 & 28 & 19 & & & 10 & 2.8 & & $4.25-6.86$ \\
\hline 102 & 4.8 & 3.0 & & 11.4 & 8.5 & 31 & & 0 & & & $1.33-3.01$ \\
\hline (275) & 4.7 & 2.4 & 290 & & & & & & & & \\
\hline
\end{tabular}


TABLE II

Clinical and laboratory date on patients with the nephrotic symdrome without coidence of glomerulonephritis *

\begin{tabular}{|c|c|c|c|c|c|c|c|c|c|c|}
\hline \multirow{2}{*}{$\begin{array}{l}\text { Name, } \\
\text { Sex, and } \\
\text { Case No. }\end{array}$} & \multirow[b]{2}{*}{ Age. } & \multirow{2}{*}{$\begin{array}{c}\text { Duration } \\
\text { of } \\
\text { illness }\end{array}$} & \multirow[b]{2}{*}{ Weight } & \multirow{2}{*}{$\begin{array}{l}\text { S.A. } \\
\text { used }\end{array}$} & \multirow[b]{2}{*}{ Edema } & \multirow{2}{*}{$\begin{array}{c}\text { Hema- } \\
\text { tocrit }\end{array}$} & \multirow[b]{2}{*}{ B.P. } & \multicolumn{3}{|c|}{ Urine } \\
\hline & & & & & & & & Spec. grav. & Alb. & $\mathrm{RBC} / 12 \mathrm{hrs}$. \\
\hline $\begin{array}{l}\text { R. W. ఠ } \\
25\end{array}$ & $\begin{array}{r}\text { years } \\
3.8\end{array}$ & $3 \mathrm{~m}$. & $\begin{array}{l}l b s . \\
52\end{array}$ & $\begin{array}{l}\text { sq. } m . \\
0.69\end{array}$ & +++ & $\begin{array}{l}\% \\
32\end{array}$ & $\begin{array}{c}\underset{\mathrm{mm}}{\mathrm{Hg}} \mathrm{Hg} \\
138 / 85-122 / 75\end{array}$ & 1019 & $+t+t$ & $\begin{array}{l}\text { 40/hpf } \\
\text { (spun) }\end{array}$ \\
\hline $\begin{array}{l}\text { S. M. } \% \\
26\end{array}$ & 2.0 & $3 \mathrm{w}$. & 26 & 0.565 & $+t$ & 42 & $110 / 74$ & $1029-1040$ & $+t+t$ & 0 \\
\hline $\begin{array}{l}\text { J. D. O7 } \\
27\end{array}$ & 4.3 & $12 \mathrm{~d}$. & 39 & 0.69 & $+t$ & & $90 / 64$ & $1021-1030$ & $+t+$ & 0 \\
\hline $\begin{array}{l}\text { D.H. } \% \\
28\end{array}$ & 3.8 & $3 \frac{1}{2} \mathbf{m}$. & 42 & 0.74 & + & 42 & $108 / 72$ & 1037 & $+t+t$ & $2.53 \mathrm{M}$ \\
\hline $\begin{array}{c}\text { P. K. } \% \\
29\end{array}$ & 3.0 & $6 \mathrm{~m}$. & 33 & 0.64 & $\begin{array}{c}\text { Edema } 0 \\
\text { but } \\
\text { ascites } \\
2150 \mathrm{cc} .\end{array}$ & 48 & $88 / 58$ & 1020 & $+t$ & 0 \\
\hline $\begin{array}{l}\text { S. diL. } \sigma^{7} \\
30\end{array}$ & 4.3 & $1 \mathrm{w}$. & 40 & 0.84 & + & 43 & $110 / 70$ & 1018 & ++ & 0 \\
\hline $\begin{array}{l}\text { S. McC. } 9 \\
31\end{array}$ & 2.3 & $5 \mathrm{w}$. & 24 & 0.512 & + & 34 & $80 / 56$ & 1004 & trace & 0 \\
\hline $\begin{array}{l}\text { V.W. W } \sigma^{7} \\
32\end{array}$ & $\begin{array}{r}9.3 \\
12.7\end{array}$ & $\begin{array}{l}38 \mathrm{~m} . \\
78 \mathrm{~m} .\end{array}$ & $\begin{array}{r}79 \\
112 \\
\end{array}$ & $\begin{array}{l}1.19 \\
1.50\end{array}$ & $\begin{array}{c}\text { trace } \\
0\end{array}$ & $\begin{array}{l}31 \\
35 \\
\end{array}$ & $\begin{array}{l}110 / 80 \\
116 / 58\end{array}$ & $\begin{array}{l}1020 \\
1020\end{array}$ & $\begin{array}{c}++t \\
0\end{array}$ & $\begin{array}{l}662,472 \\
1.47 \mathrm{M}\end{array}$ \\
\hline $\begin{array}{l}\text { L.S. O' } \\
33\end{array}$ & 5.6 & $16 \mathrm{~m}$. & 53 & 0.86 & minimal & 35 & $100 / 50$ & $1016-1026$ & $\begin{array}{c}+++ \\
(1.3 \mathrm{Gm} . / \mathrm{L} .)\end{array}$ & 197,333 \\
\hline $\begin{array}{l}\text { S. K. O } \\
34\end{array}$ & 6.0 & $21 \mathrm{~m}$. & 50 & 0.84 & 0 & 40 & $92 / 40$ & 1028 & $+t+t$ & 316,000 \\
\hline $\begin{array}{l}\text { V. D. } \% \\
35 \\
\end{array}$ & 11.0 & $5 \mathrm{y}$. & 100 & 1.36 & tr. & 36 & $120 / 65$ & 1031 & $+t+$ & $1.1 \mathrm{M}$. \\
\hline $\begin{array}{c}\text { P.W. } 9 \\
36 \\
\end{array}$ & 1.5 & $6 \mathrm{w}$. & 30 & 0.62 & $+t$ & 31 & $(125 / 75)$ & 1032 & $\begin{array}{c}++++ \\
(28 \mathrm{Gm} . / \mathrm{L} .)\end{array}$ & $6.6 \mathrm{M}$. \\
\hline $\begin{array}{l}\text { T.L. の } \\
37\end{array}$ & $\begin{array}{l}1.6 \\
1.7 \\
\end{array}$ & $\begin{array}{l}2 \mathrm{~m} . \\
3 \mathrm{~m} .\end{array}$ & $\begin{array}{l}32 \\
23 \\
\end{array}$ & $\begin{array}{l}0.506 \\
0.506\end{array}$ & $\begin{array}{c}++++ \\
\text { tr. }\end{array}$ & $\begin{array}{l}37 \\
26 \\
\end{array}$ & $144 / 100$ & $\begin{array}{c}1022-1033 \\
1015 \\
\end{array}$ & $\begin{array}{l}+++t \\
+++t\end{array}$ & $\begin{array}{l}147,000 \\
10-15 / \mathrm{hpf}\end{array}$ \\
\hline $\begin{array}{l}\text { P.diP. } \% \\
38 \\
\end{array}$ & $\begin{array}{l}4.2 \\
4.8 \\
\end{array}$ & $\begin{array}{r}4 \mathrm{~m} . \\
11 \mathrm{~m} .\end{array}$ & $\begin{array}{l}48 \\
49 \\
\end{array}$ & $\begin{array}{l}0.66 \\
0.72 \\
\end{array}$ & $\begin{array}{c}+++ \\
+++\end{array}$ & $\begin{array}{l}30 \\
47 \\
\end{array}$ & $\begin{array}{l}110 / 60 \\
120 / 84 \\
\end{array}$ & $\begin{array}{l}1018 \\
1004 \\
\end{array}$ & $\begin{array}{c}+t \\
++t+\end{array}$ & $\begin{array}{l}0 \\
0-1\end{array}$ \\
\hline $\begin{array}{l}\text { P. M. } 9 \\
39\end{array}$ & 6.7 & $42 \mathrm{~m}$. & 55 & 0.79 & ++ & 34 & $90 / 55$ & 1019 & $+++t$ & 0 \\
\hline $\begin{array}{l}\text { J. H. } \sigma^{7} \\
40\end{array}$ & 4.0 & $16 \mathrm{~m}$. & 36 & 0.71 & tr. & & $132 / 54$ & 1014 & $+t+t$ & $\begin{array}{c}0 \\
\text { many times } \\
\end{array}$ \\
\hline $\begin{array}{c}\text { J. M. } \\
41\end{array}$ & $\begin{array}{l}3.4 \\
3.8 \\
4.0 \\
\end{array}$ & $\begin{array}{l}9 \mathrm{~d} . \\
4 \mathrm{~m} . \\
7 \mathrm{~m} .\end{array}$ & $\begin{array}{l}36 \\
49 \\
35\end{array}$ & $\begin{array}{l}0.65 \\
0.65 \\
0.65 \\
\end{array}$ & $\begin{array}{l}++++ \\
++++ \\
++++\end{array}$ & 42 & & 1023 & $+t+t$ & 0 \\
\hline $\begin{array}{l}\text { J. To. } \% \\
42 \\
\end{array}$ & 2.5 & $2 \mathrm{~m}$ & 33 & 0.655 & + & 40 & $95 / 60$ & 1027 & $+t+t$ & 0 \\
\hline $\begin{array}{l}\text { M. G. O } \\
43\end{array}$ & $\begin{array}{l}1.7 \\
2.2 \\
2.6 \\
\end{array}$ & $\begin{array}{r}3 \mathrm{w} . \\
7 \mathrm{~m} . \\
11 \mathrm{~m} . \\
\end{array}$ & $\begin{array}{l}33 \\
38 \\
30 \\
\end{array}$ & $\begin{array}{l}0.577 \\
0.577 \\
0.62 \\
\end{array}$ & $\begin{array}{c}+++ \\
++++ \\
0\end{array}$ & $\begin{array}{l}40 \\
32 \\
40 \\
\end{array}$ & $\begin{array}{l}96 / 60 \\
80 / 50\end{array}$ & $\begin{array}{l}1022 \\
1015 \\
1022 \\
\end{array}$ & $\begin{array}{c}+++t \\
+++t \\
++\end{array}$ & $\begin{array}{l}0-1 \\
3-5 / \mathrm{hpf} \\
0-3 / \mathrm{hpf}\end{array}$ \\
\hline R. J. O & $\begin{array}{l}4.0 \\
4.2 \\
\end{array}$ & $\begin{array}{l}1 \mathrm{w} . \text { or } \\
1 \mathrm{y} . ? \\
2 \mathrm{~m} . ?\end{array}$ & $\begin{array}{l}36 \\
37 \\
\end{array}$ & $\begin{array}{l}0.67 \\
0.68 \\
\end{array}$ & tr. & 45 & $\begin{array}{r}95 / 60 \\
100 / 60 \\
\end{array}$ & $\begin{array}{r}1019 \\
1020 \\
\end{array}$ & $+t+$ & $\begin{array}{l}\text { "rare" } \\
32,634 \\
\end{array}$ \\
\hline $\begin{array}{l}\text { M. Po. } \sigma^{7} \\
45\end{array}$ & $\begin{array}{l}4.1 \\
4.6 \\
4.6\end{array}$ & $\begin{array}{l}15 \mathrm{~m} \\
21 \mathrm{~m} \\
21 \mathrm{~m}\end{array}$ & $\begin{array}{l}39 \\
42 \\
42\end{array}$ & $\begin{array}{l}0.705 \\
0.76 \\
0.76\end{array}$ & $\begin{array}{c}\text { trace } \\
0 \\
0\end{array}$ & $\begin{array}{l}40 \\
42 \\
44\end{array}$ & $\begin{array}{l}106 / 60 \\
112 / 70\end{array}$ & $\begin{array}{l}1022 \\
1025 \\
1024\end{array}$ & $\begin{array}{c}++t \\
0 \\
0\end{array}$ & $\begin{array}{c}293,333 \\
0 \\
548,888\end{array}$ \\
\hline
\end{tabular}

* See Appendix $\mathrm{C}$ for remarks and clinical observations on these patients. 
TABLE II-Continued

Clinical and laboratory data on patients with the nephrotic syndrome without evidence of glomerulonephritis *

\begin{tabular}{|c|c|c|c|c|c|c|c|c|c|c|c|}
\hline \multicolumn{4}{|c|}{ Blood serum } & \multirow[b]{2}{*}{ GFR } & \multirow[b]{2}{*}{$\mathrm{Cu}$} & \multirow[b]{2}{*}{ RPF } & \multirow[b]{2}{*}{ FF } & \multirow[b]{2}{*}{ TmPAH } & \multirow[b]{2}{*}{$\underset{\text { TmPAH }}{\text { GFR/ }}$} & \multirow[b]{2}{*}{$\underset{\text { TmPAH }}{\mathrm{RPF} /}$} & \multirow[b]{2}{*}{$\begin{array}{l}\text { Range of } \\
\text { U.F. }\end{array}$} \\
\hline $\begin{array}{l}\text { Urea-N } \\
\text { or } \\
\text { (NPN) }\end{array}$ & T.P. & Alb. & $\begin{array}{l}\text { Choles- } \\
\text { terol }\end{array}$ & & & & & & & & \\
\hline $\begin{array}{r}\text { mg. \% } \\
16.7\end{array}$ & $\begin{array}{l}G m . \% \\
2.8-5.2\end{array}$ & $\begin{array}{c}G m . \% \\
0.7\end{array}$ & $m g . \%$ & $1^{c c . / m i}$ & $\begin{array}{l}2 . / 1.73 \mathrm{sq} . \\
16\end{array}$ & $103 ?$ & $0.185 ?$ & $\begin{array}{c}m g . / \min . / \\
1.73 \text { sq. m. } \\
11.8\end{array}$ & 1.61 & $2.93 ?$ & $\begin{array}{c}c c . / \min . / \\
1.73 \text { sq. } m . \\
1.12-2.93\end{array}$ \\
\hline 16.1 & 4.2 & 2.1 & 450 & 57 & 29 & 507 & 0.112 & 55 & 1.04 & 9.2 & $0.65-2.61$ \\
\hline 10.2 & 5.1 & 2.1 & 370 & $\begin{array}{l}103 \mathrm{M} \\
104 \mathrm{I}\end{array}$ & 64.5 & 492 & 0.217 & 93 & 1.11 & 5.3 & $6.43-11.15$ \\
\hline 18.6 & 3.6 & 0.9 & & 107 & 57 & 563 & 0.190 & 114 & 0.94 & 4.9 & $0.83-2.56$ \\
\hline 14.0 & $(4.7)$ & $(2.2)$ & (265) & 114.5 & 57 & 404 & 0.283 & 75 & 1.53 & 5.4 & $1.63-3.46$ \\
\hline 12.2 & 5.3 & 2.4 & 307 & 120.5 & 69 & 545 & 0.221 & 107 & 1.13 & 5.1 & $0.69-3.80$ \\
\hline 15.2 & 5.4 & 2.8 & 372 & 123 & 68 & 529 & 0.233 & $105 ?$ & $1.17 ?$ & $5.0 ?$ & $1.46-3.99$ \\
\hline $\begin{array}{l}11.9 \\
10.6\end{array}$ & 5.5 & 3.3 & $\begin{array}{c}230 \\
(350)\end{array}$ & $\begin{array}{l}129 \\
120\end{array}$ & $\begin{array}{l}69 \\
74\end{array}$ & $\begin{array}{l}888 \\
628\end{array}$ & $\begin{array}{l}0.145 \\
0.191\end{array}$ & $\begin{array}{l}118 \\
106.5\end{array}$ & $\begin{array}{l}1.09 \\
1.13\end{array}$ & $\begin{array}{l}7.5 \\
5.9\end{array}$ & $\begin{array}{l}2.61-4.53 \\
3.19-5.58\end{array}$ \\
\hline 11.05 & 5.2 & 2.1 & 533 & 130 & 71 & 590 & 0.220 & 158 & 0.82 & 3.7 & $2.86-11.9$ \\
\hline 12.9 & 5.3 & 3.1 & & 136 & 82 & 609 & 0.223 & 130 & 1.05 & 4.7 & \\
\hline 11.8 & 4.96 & 2.32 & 400 & 139 & 85 & 886 & 0.137 & 109 & 1.28 & 8.1 & $1.89-4.85$ \\
\hline 22.8 & $(5.2)$ & (1.9) & (544) & 139.5 & 35 & 620 & 0.225 & 100 & 1.40 & 6.2 & $1.24-1.98$ \\
\hline $\begin{array}{r}13.0 \\
112.1\end{array}$ & $\begin{array}{l}4.4 \\
5.4\end{array}$ & 1.3 & $\begin{array}{c}(573) \\
895\end{array}$ & $\begin{array}{c}140 \\
10.2 \\
\end{array}$ & $\begin{array}{r}50 \\
4 \\
\end{array}$ & 184 & 0.055 & 25.6 & 0.40 & 7.2 & $\begin{array}{l}0.77-1.07 \\
0.77-2.07 \\
\end{array}$ \\
\hline $\begin{array}{r}6.9 \\
10.3 \\
\end{array}$ & $\begin{array}{l}5.5 \\
4.9 \\
\end{array}$ & $\begin{array}{l}2.8 \\
2.0\end{array}$ & $\begin{array}{l}491 \\
805 \\
\end{array}$ & $\begin{array}{l}140 \\
159 \\
\end{array}$ & $\begin{array}{l}97 \\
68 \\
\end{array}$ & $\begin{array}{r}1206 \\
829 \\
\end{array}$ & $\begin{array}{l}0.116 \\
0.191\end{array}$ & $\begin{array}{l}201 \\
135 \\
\end{array}$ & $\begin{array}{l}0.70 \\
1.17\end{array}$ & $\begin{array}{l}6.0 \\
6.1\end{array}$ & $\begin{array}{l}2.17-5.24 \\
1.36-4.20\end{array}$ \\
\hline 10.6 & 4.1 & $(0.9)$ & (523) & 172 & 81 & 1170 & 0.14 & $>170$ & & & $3.62-9.85$ \\
\hline 16.8 & 6.1 & 2.0 & 460 & 176 & 46 & 676 & 0.260 & 145 & & & $1.51-2.33$ \\
\hline $\begin{array}{l}10 \\
8.95\end{array}$ & 6.1 & 3.0 & 711 & $\begin{array}{l}131 \\
158 \\
188 ?\end{array}$ & $76 ?$ & 728 & 0.180 & $\begin{array}{l}133 ? \\
163 ?\end{array}$ & $0.98 ?$ & $5.5 ?$ & $\begin{array}{l}1.14-2.00 \\
1.58-4.63\end{array}$ \\
\hline 16 & 5.12 & 1.86 & 352 & 186 & & 830 & 0.224 & 101.5 & 1.83 & 8.2 & $1.74-4.04$ \\
\hline $\begin{array}{r}11.4 \\
10.7 \\
6.5 \\
\end{array}$ & $\begin{array}{c}(3.3) \\
3.4 \\
3.5 \\
\end{array}$ & $\begin{array}{c}(1.3) \\
1.8\end{array}$ & $\begin{array}{c}(680) \\
705\end{array}$ & $\begin{array}{r}118 \\
73.5 \\
191.5\end{array}$ & $\begin{array}{c}58.5 \\
44 \\
133.5\end{array}$ & $\begin{array}{l}621 \\
854 \\
693 \\
\end{array}$ & $\begin{array}{l}0.190 \\
0.086 \\
0.276\end{array}$ & $\begin{array}{r}90 \\
75 \\
129\end{array}$ & $\begin{array}{l}1.31 \\
0.98 \\
1.48\end{array}$ & $\begin{array}{r}6.9 \\
11.4 \\
5.4\end{array}$ & $\begin{array}{l}1.12-4.77 \\
1.41-3.80 \\
2.50-4.64\end{array}$ \\
\hline 7.8 & 5.2 & & 653 & 125 & & 631 & 0.198 & & & & \\
\hline 11.9 & $(6.4)$ & (3.3) & & 223 & & 1074 & 0.207 & 109 & 2.05 & 9.9 & $2.26-7.62$ \\
\hline $\begin{array}{l}8.1 \\
5.6 \\
5.6\end{array}$ & $\begin{array}{l}6.8 \\
7.1\end{array}$ & $\begin{array}{l}4.1 \\
4.8\end{array}$ & $\begin{array}{l}468 \\
173\end{array}$ & $\begin{array}{l}258 \\
308 \\
228\end{array}$ & $\begin{array}{l}114 \\
136.5 \\
158\end{array}$ & $\begin{array}{l}1907 \\
1045\end{array}$ & $\begin{array}{l}0.135 \\
0.295\end{array}$ & $\begin{array}{l}181 \\
137 \\
146.5\end{array}$ & $\begin{array}{l}1.43 \\
2.25 \\
1.56\end{array}$ & $\begin{array}{r}10.5 \\
7.6\end{array}$ & $\begin{array}{l}2.42-4.72 \\
1.95-4.87 \\
4.13-5.00\end{array}$ \\
\hline
\end{tabular}


tion rate. ${ }^{3}$ The clearance tests were performed after a light breakfast. Details of the methods and laboratory procedures are described in a previous communication (10). Criticism of the methods and of their application in patients with diseased kidneys is discussed in Appendix A. The results of the laboratory studies and significant clinical data are listed in Tables I and II, and Appendixes $\mathrm{B}$ and $\mathrm{C}$.

\section{RESULTS}

Various patterns in the clinical course were noted in the group of patients classified as having the nephrotic syndrome with nephritis. These patterns overlapped in individual patients.

\section{Patients with rapidly progressive renal failure}

Some patients had clinically only or predominantly "lipoid nephrosis" when seen early in their disease (Cases 1 to 8 ). In other patients in this group (Cases 9 to 13), who did not necessarily have a longer history of disease prior to study, glomerulonephritis was diagnosed initially, chiefly on the basis of a persistent hypertension or azotemia. Microscopic hematuria was present in all but one of these latter cases, but was not a striking feature in any.

The initial clearance test performed 3 days to 8 months (mean 2.9 months) after onset of symptoms already showed reduction of the GFR to 50 per cent or less of normal in Cases 4, 5, 7, 8; in others the filtration rate was initially within normal limits but showed a progressive, often rapid, decline on subsequent observations (see Figure 1). In all of these patients the filtration fraction (FF) was below normal while the RPF, except in the advanced stage of the disease, was normal or even slightly higher than average. One patient, S. S., had only one clearance test four months after onset of her disease, which revealed a normal GFR but low FF and a high TmPAH; this patient died of renal insufficiency a year later.

The TmPAH, when determined during the first three months of the disease, was normal even in the cases with a reduced GFR. In three cases having symptoms of 3 to 11 months' duration when first studied, the TmPAH was found to be reduced

\footnotetext{
${ }^{3}$ For calculating the amount of PAH filtered at the glomerulus, the plasma level of $\mathrm{PAH}$ was multiplied by the average F.W. factor of 0.83 (9); no attempt was made to calculate this factor individually from the plasma protein concentration.
}

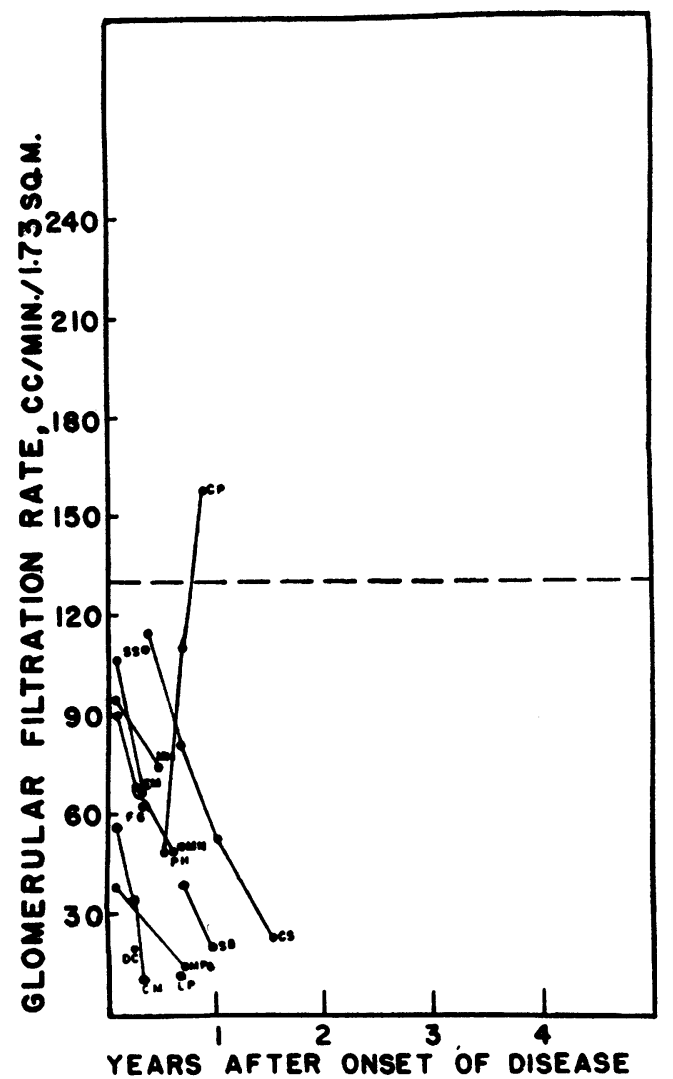

Fig. 1. Glomerular Filtration Rate in Cases of the Nephrotic Syndrome with Rapidly Progressive Glomerulonephritis, Group I, Case No. 1 to 13.

The horizontal line indicates the mean normal value for older children (10). Each dot represents the average of 3 to 4 consecutive clearance periods.

to less than 30 per cent of the normal value, and a fall of the tubular excretory capacity was observed in all the patients studied during the later stages of the disease, except in one patient (Case 10).

The rapid fall of renal function as determined by clearance tests was often the first sign indicating a bad prognosis. Eleven of the 13 patients in this group have died, 8 of them within 18 months after the onset of symptoms.

\section{Patients with a prolonged course of nephrotic syndrome with glomerulonephritis}

Nine patients were asymptomatic for periods of one up to seven years (Cases 14-22). Seven of them began their disease with an episode of edema with or without hypertension and/or hematuria. During the latent period, persistent renal disease 
in these patients was manifest only by laboratory tests (see Table I). Two of these patients (R. T. and A. P.) never had symptoms referable to their kidney disease, and their disease was discovered only by means of a routine urinalysis. In two patients (J. E. and J. J.) the laboratory signs of renal disease also disappeared for periods up to several years.

In this group of nine patients, the renal clearances usually remained stationary for several years. It may be pointed out that a constant clearance value per unit of surface area in a child means that the functional capacity of these diseased kidneys increases in proportion to the child's growth.

The glomerular filtration rate in some of these patients (see Figure 2) remained in the lower range of normal, in one young child (A. P.) at a level slightly above 50 per cent of normal. One patient (M. C.) had for at least two years a GFR considerably above the normal range. Progres- sive decline of his GFR began during the sixth year of his illness simultaneously with the reappearance of very mild edema and arrest of growth. He died of hypertensive heart disease and renal insufficiency at the end of the eighth year of his illness.

Remarkable improvement with trebling of the GFR and TmPAH, after considerable reduction in the initial stage of the disease, occurred in patient J. J. Rapid recovery of greatly diminished functions was also noted in C. A. during the eighth month of her disease, and M. C. had a rise in his GFR from a low normal to a very high value, strangely enough immediately following mild scarlet fever, at a time when he was edema-free and had been so for several years. A low filtration fraction was not as constant in this group as in all cases of Group I, although all but one of these patients (J. E.) showed this feature at some time in their course.

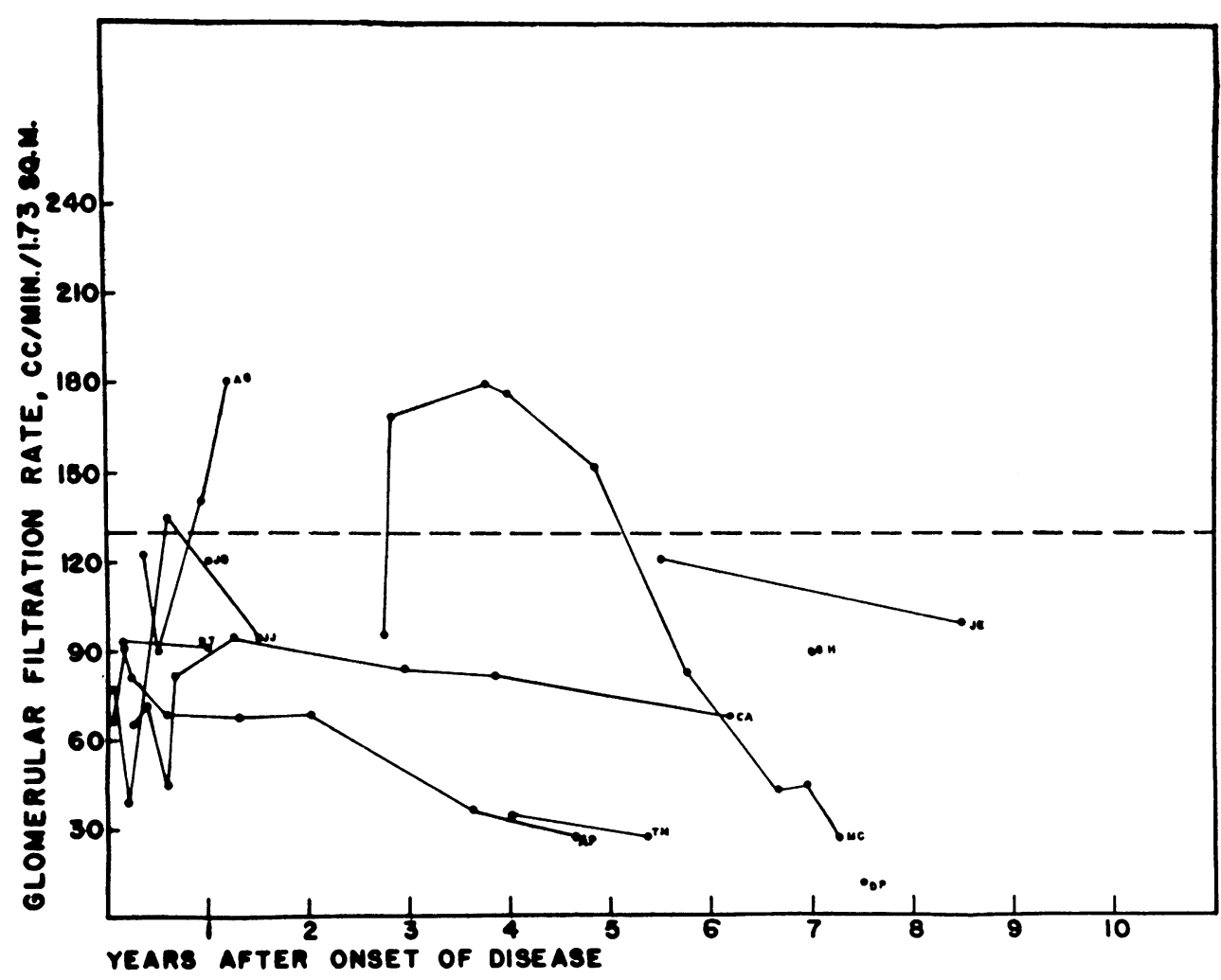

Fig. 2. Glomerular Filtration Rate in Cases of the Nephrotic Syndrome with Glomerulonephritis with Protracted Course and Periods of Latent Disease, Group II, Case Nos. 14 To 24

Symbols as in Figure 1. 
The patients in this group tended to have a TmPAH in the upper range of normal or even above normal sometime during the course of their disease, often after several years. This was unrelated to changes in the GFR. Only two patients, C. A. and J. J., had a transitory depression of this tubular function in the early stage of their disease, and in two patients (M. C. and A. P.) the TmPAH fell from high to low values during the terminal stage. Hypertension was absent or mild for many years in this group of patients. All but two are alive one to ten years after the initial observation.

Two patients were seen only in the terminal stage of chronic glomerulonephritis with little or no edema but with polyuria, isosthenuria, and marked persistent hypertension (Cases 23 and 24; T. M. and D. P.). These cases probably represent the endstage of the course described for the patients of Group II ; both had a history of an asymptomatic, apparently quiescent disease for four and seven years, respectively, following an episode of nephrotic syndrome. In these two patients the GFR was greatly reduced (to 28 and $11 \mathrm{cc}$. per min. per 1.73 sq.m., respectively), but the deterioration of the tubular excretory capacity was even more striking ( 0 in D. P.), as has also been observed in terminal nephritis of adults $(7,8)$. The effective renal plasma flow and, therefore, the filtration fraction could not be measured because of the low TmPAH which prevented complete clearance of $\mathrm{PAH}$ even at low plasma levels.

\section{Patients with the nephrotic syndrome without evidence of glomerulonephritis, presumed "lipoid nephrosis"}

The significance of the clearance studies in the 21 patients classified as nephrotic syndrome without glomerulonephritis cannot be interpreted as definitely as those in other groups because in many of them only a single determination was made.

Nineteen of these 21 patients had normal or super-normal GFRs (Figure 3). Two children (S. M. and R. W.) with a low GFR died of peritonitis complicating the nephrotic syndrome one year after having been studied and at autopsy showed no evidence of glomerulonephritis on routine histologic examination. (Special stains were not made.) In R. W. the low GFR was observed immediately following acute pneumonia with peri- tonitis. In two other patients who originally had normal GFRs (M. G. and T. L.), the filtration rates were depressed during complications of the disease; massive edema occurred in one child and thrombosis of the inferior vena cava and left renal vein in the other. In the child with massive edema the GFR rose to a super-normal level with the disappearance of edema three months later.

The FF in this group of patients, in contrast to that in patients with evidence of glomerulonephritis, was usually normal or high. In three patients the FF was low during a complication of the disease.

The TmPAH was normal or increased in all but two patients (R. W. and T. L.). In these two cases the TmPAH was determined during the above-mentioned complications when the GFR also was reduced; in T. L. only one kidney was functioning at the time of the determination.

\section{DISCUSSION}

\section{A. Interpretation of tests in diseased kidneys}

In trying to interpret the results of clearance measurements, it must be remembered that what appears in the urine is the sum of the products of a multitude of individual nephrons. In the normal kidney these nephrons are of sufficient uniformity morphologically to justify the assumption that every one of them performs an approximately equal portion of the overall functions. However, this is probably not true for the kidney in the various forms of nephritis or nephrosis. Here atrophy and hypertrophy alternate in various nephrons and even in parts of the same nephron, and may be associated with alterations in anatomical patterns, the functional implications of which are unknown. Oliver (11), upon finding hypertrophied tubules without attached glomeruli, has gone so far as to suggest the possibility that such tubules may take over functions usually assigned to the glomeruli. Theoretical considerations emphasize the disproportion of functional alterations in disease: If among 100 normal nephrons one "impotent tubule" fails to reabsorb the filtered water and sodium, the total renal output of water and sodium will be doubled. But even a much larger number of dead tubules may not affect the clearance of $\mathrm{PAH}$ which can be effected by "vicarious clearance" or diffusion in interstitial fluid (12). Thus, 


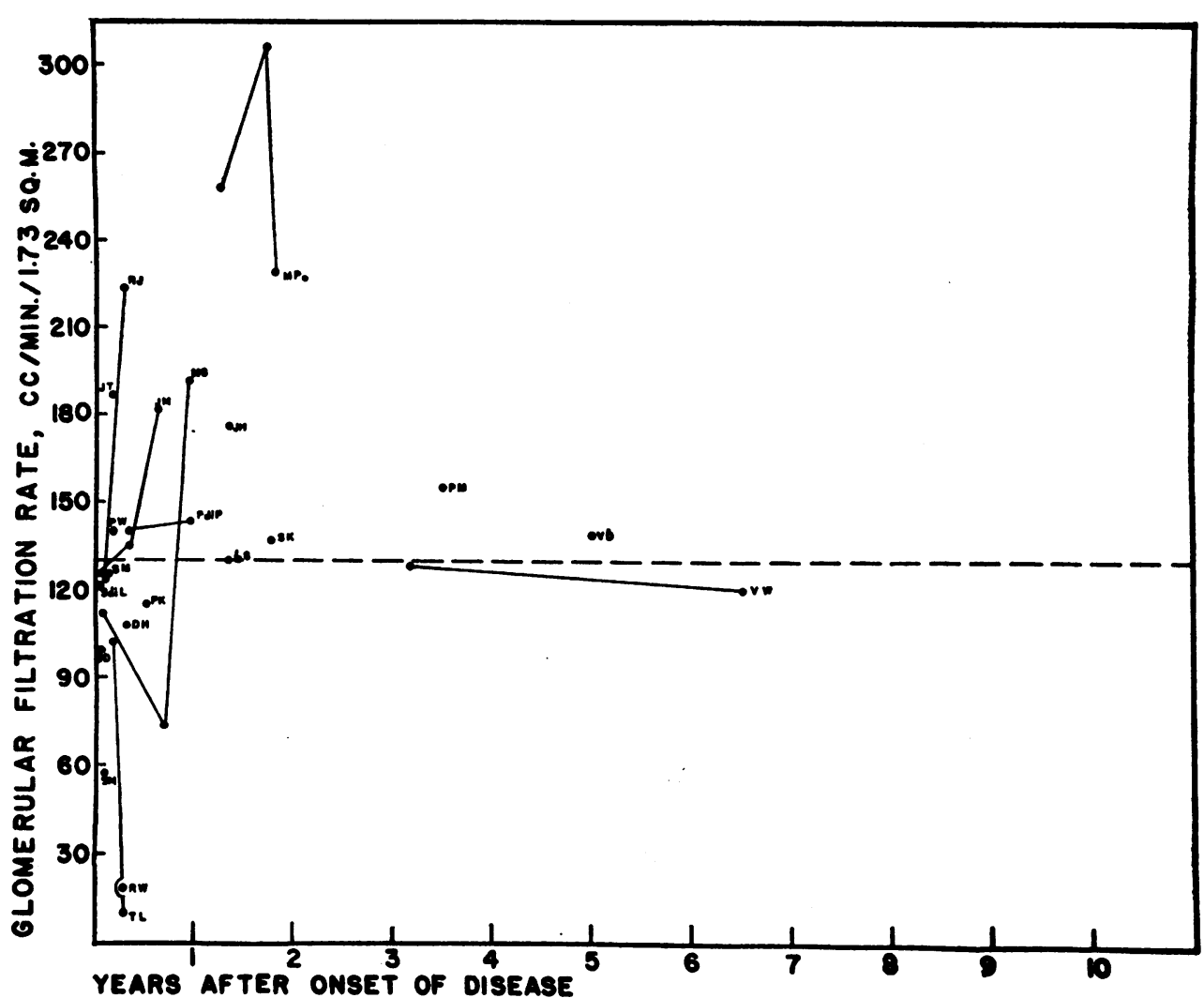

Fig. 3. Glomerular Filtration Rate in Cases of the Nephrotic Syndrome without Evidence of Glomerulonephritis, Group III, Case Nos. 25 to 45

Symbols as in Figure 1.

mannitol clearance, urea clearance, TmPAH, and even the urine flow may have an entirely different significance in the diseased kidney than in the normal one.

\section{B. Correlation of symptomatology with renal functions}

However, repeating such measurements over long periods in the course of renal diseases offers one means of correlating clinical and pathological information, even though the interpretation of the figures may have to be fundamentally changed in the light of future knowledge. Clinical symptomatology gives no indication of the nature and extent of the pathologic lesion. The most obvious symptom, anasarca, may be present at a time when anatomic structure or clearances of mannitol and $\mathrm{PAH}$ are altered only minimally or not at all, while a patient in the terminal stage of nephritis, with complete distortion of the functions and structure of his kidneys, may be almost asymptomatic. The studies here reported may give some insight into the nature and extent of the functional distortion and thereby perhaps into the prognosis of individual cases.

\section{Diagnostic and prognostic value of clearances and other laboratory studies}

Keeping in mind the reservations implied in the preceding two paragraphs, the results of the clearance studies may be considered in respect to their value as diagnostic and prognostic aids in the individual case.

The prognosis of children with nephrotic syndrome depends in a large measure on whether or not they have, or will develop, glomerulonephritis. Therefore, Table III was compiled in order to determine, if possible, which diagnostic features, when observed during the initial stage of the disease, were most significant in the light of the final 
TABLE III

Final evaluation *

\begin{tabular}{|c|c|c|c|c|c|}
\hline \multirow[b]{3}{*}{ Early signs and symptoms } & \multicolumn{5}{|c|}{ Nephrotic syndrome } \\
\hline & \multicolumn{2}{|c|}{ With glomerulonephritis } & \multicolumn{3}{|c|}{ Without glomerulonephritis } \\
\hline & Present & Absent & Present & Absent & $x^{2}$ \\
\hline $\begin{array}{l}\text { Gross hematuria } \\
\text { Repeated microscopic hematuria } \\
\text { Elevated BPt } \\
\text { Elevated BUN above } 22 \mathrm{mg} . / 100 \mathrm{cc} \text {. } \\
\text { GFR below } 100 \mathrm{cc} / \mathrm{min} . / 1.73 \mathrm{M}^{2} \\
\text { FF below } 0.17 \\
\text { TmPAH below } 50 \mathrm{mg} . / \mathrm{min} . / 1.73 \mathrm{M}^{2}\end{array}$ & $\begin{array}{r}5 \\
13 \\
7(-1 \ddagger) \\
4 \\
12(-1 \ddagger) \\
13 \\
4(-1 \ddagger)\end{array}$ & $\begin{array}{r}11 \\
4 \\
10 \\
13 \\
5 \\
1 \\
12\end{array}$ & $\begin{array}{l}0 \\
2 \\
2 \\
0 \\
2 \\
3(-2 \ddagger) \\
1\end{array}$ & $\begin{array}{r}13 \\
11 \\
11 \\
13 \\
11 \\
8 \\
11\end{array}$ & $\begin{array}{r}6.4 \\
12.1 \\
0.4\end{array}$ \\
\hline
\end{tabular}

* This table summarizes the early diagnostic features of those patients whose final diagnosis was established by autopsy or recovery or unequivocal signs of glomerular disease on prolonged observation. It is arbitrarily assumed that patients who recovered completely did not have glomerulonephritis.

T. M. and D. P. are omitted because they were not observed early in their disease. L. S., S. K., P. diP., A. G. V. D., P. M., J. M., F. G., J. J., J. B., G. H., D. H., S. McC. are omitted because the final diagnosis was not definitely established.

t Diastolic above $80 \mathrm{~mm}$. $\mathrm{Hg}$ in children under 10, above $90 \mathrm{~mm}$. in children over 10 years of age.

$\ddagger$ These patients on subsequent observations had reversed findings.

outcome. It is seen that gross hematuria never occurred in patients who did not subsequently show other evidence of nephritis. But even of the patients who had nephritis, only five ever manifested gross hematuria; so this sign seems important only when it is present. Repeated microscopic hematuria was present in all but four patients who ultimately proved to have nephritis, and was absent in all but two who did not have it. The blood pressure is rarely elevated early in either type of patient and is, therefore, not a satisfactory criterion. The same is true for the blood urea nitrogen, although its elevation might be significant when present.

Both the GFR and the FF show significant differences between the two groups of cases. In at least two thirds of the patients who were eventually proven to have glomerulonephritis, the GFR was below $100 \mathrm{cc}$. per min. per 1.73 sq.m., while this occurred only in two cases in the other group. However, in an individual case a normal or even high GFR does not rule out the existence of glomerulonephritis. The filtration rate itself is, therefore, not a reliable differential diagnostic sign, except when it is markedly and persistently reduced; it may be normal or even supernormal for years in patients with known glomerulonephritis. However, all but one of these patients (J. E.) had a FF below 0.17 . Such a low FF was only observed transiently in three patients with presumed "lipoid nephrosis." A normal or high FF thus seems to be strong evidence against the presence of glo- merulonephritis (provided, of course, that the patient's other functions are not so impaired as to make one suspect incomplete extraction of $\mathrm{PAH}$ ) and a low FF may be the first sign of otherwise unsuspected glomerulonephritis (Cases 1, 3, 4). The FF seems to be the most consistently reliable criterion in this respect on a statistical basis, although there are individual exceptions. The TmPAH is normal up to relatively late stages of the disease, whether glomerulonephritis is present or not; it is thus of no diagnostic significance.

H. Smith (12) states that a glomerular lesion may best be revealed by a lowered $\frac{\text { GFR }}{\text { TmPAH }}$ ratio. This ratio was reduced below normal in the majority of the tests on patients with glomerulonephritis here reported (mean 1.295), except in the terminal stages when tubular insufficiency became prominent. However, this ratio was similarly reduced (mean 1.20) in the group of patients considered to have presumed lipoid nephrosis without glomerulonephritis. It must be remembered that anatomically demonstrable hypertrophy of tubular tissue is characteristic of nephrotic kidneys. High functional activity might correspond to this hypertrophy, and without proportional elevation of glomerular function this would also result in a lowering of the $\frac{\mathrm{GFR}}{\mathrm{TmPAH}}$ ratio, in the absence of a glomerular lesion. Figure 4 and Table II illustrate the fact that in the majority of the tests done on children in Group III (so-called lipoid nephrosis) 


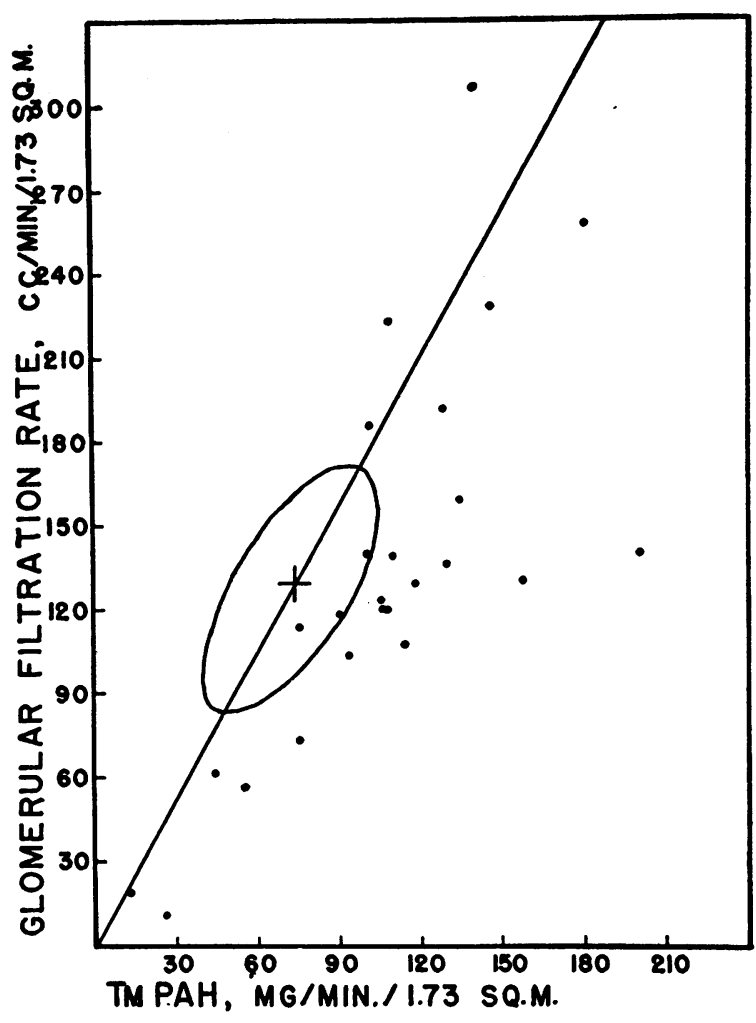

Fig. 4. Ratio of GFR to TMPAH in Cases of the Nephrotic Syndrome without Evidence of GlomeruLONEPHRITIS (GROUP III)

The diagonal line represents the mean normal value for older children (10) and the ellipse comprises 70 per cent of normal values.

the low $\frac{\text { GFR }}{\text { TmPAH }}$ ratio was due to a high $\mathrm{TmPAH}$ which was above $90 \mathrm{mg}$. per min. per 1.73 sq.m. in all but six cases. In Figure 5, which portrays data on the patients in Groups I and II, some of the points are in the same area as most of those in Figure 4, while a larger group aggregate in the area which represents a low GFR with a normal or even low TmPAH. There is thus evidence of increased tubular function in many cases of the nephrotic syndrome. A similar condition is observed late in the remaining kidney after unilateral nephrectomy $(13,14)$. Increased intrarenal pressure which might reasonably be expected in the edematous kidney may also reduce the GFR and so depress the ratio. It would seem unjustified, therefore, to use a lowered $\frac{\text { GFR }}{\text { TmPAH }}$ ratio as an argument to prove that all patients with nephrotic syndrome have glomerular disease.
In normal kidneys the $\frac{\mathrm{RPF}}{\mathrm{TmPAH}}$ ratio may be accepted as a measure of perfusion of functioning parenchyma. For reasons discussed above, the significance of this ratio may be doubtful with diseased kidneys; low values particularly may hardly be interpreted with any assurance and high values may in some cases be due to "vicarious clearance," yet in other cases might indicate a relative hyperemia of the tissues excreting PAH. On inspection of Figures 6 and 7 it appears that in the patients of Group III (nephrotic syndrome without evidence of nephritis, Figure 6) the $\frac{\mathrm{RPF}}{\mathrm{TmPAH}}$ ratio is almost always within or below the normal range. By contrast, eight of the patients with glomerulonephritis associated with the nephrotic syndrome (Figure 7) had episodes in the course of their disease when the ratio was very high. Such episodes were usually transitory and occurred mostly during the first year of the disease and in two pa-

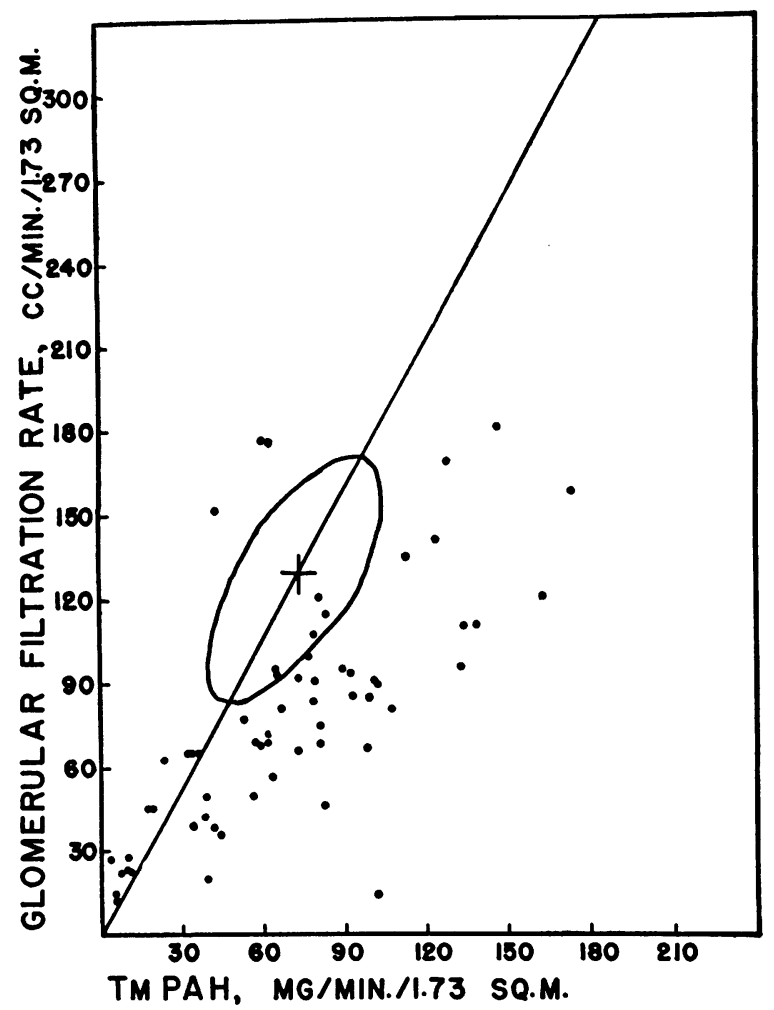

Fig. 5. Ratio of GFR to TMPAH in Cases of the Nephrotic Syndrome with Glomerulonephritis (GRoups I AND II)

Symbols as in Figure 4. 
tients (C. S. and M. C.) during the terminal progressive phase. Similar episodes were observed by other investigators $(7,8)$. It may be speculated that a high $\frac{\mathrm{RPF}}{\mathrm{TmPAH}}$ ratio in these episodes indicated hyperemia, possibly associated with active inflammatory processes in the kidneys at the time. With one exception (M. C., 47 and 58 months after onset of the disease), the ratio was not high in the latent stages of the disease. It was not possible from the available data to correlate the episodes of high $\frac{\mathrm{RPF}}{\mathrm{TmPAH}}$ ratio with other signs of exacerbation of the disease. In only two cases (9 and 16) did a high ratio coincide with the maximal microscopic hematuria recorded in these patients.

\section{Correlation of urea clearance with GFR}

The urea clearance has shown only a rough correlation with mannitol clearance; in individual cases the ratio of urea clearance to mannitol clearance varied from 0.22 to 0.87 . Estimation of the GFR, or even of a trend of a changing GFR from the urea clearance test alone therefore appears unwarranted (15).

\section{E. Relation of plasma urea nitrogen $(B U N)$ to urea clearance}

The BUN was frequently within the "normal" range, even in advanced cases of glomerulonephritis with impaired urea clearance. The reason probably lies in the poor appetite of these children, which frequently results in a very low protein intake. Figure 8 illustrates the relationship between BUN and urea clearance in the patients; by referring to the lines which indicate a constant urea nitrogen output, it is seen that many of these children had a much lower total nitrogen output and, therefore, BUN than would be expected with an average protein intake at the observed clearance rate.

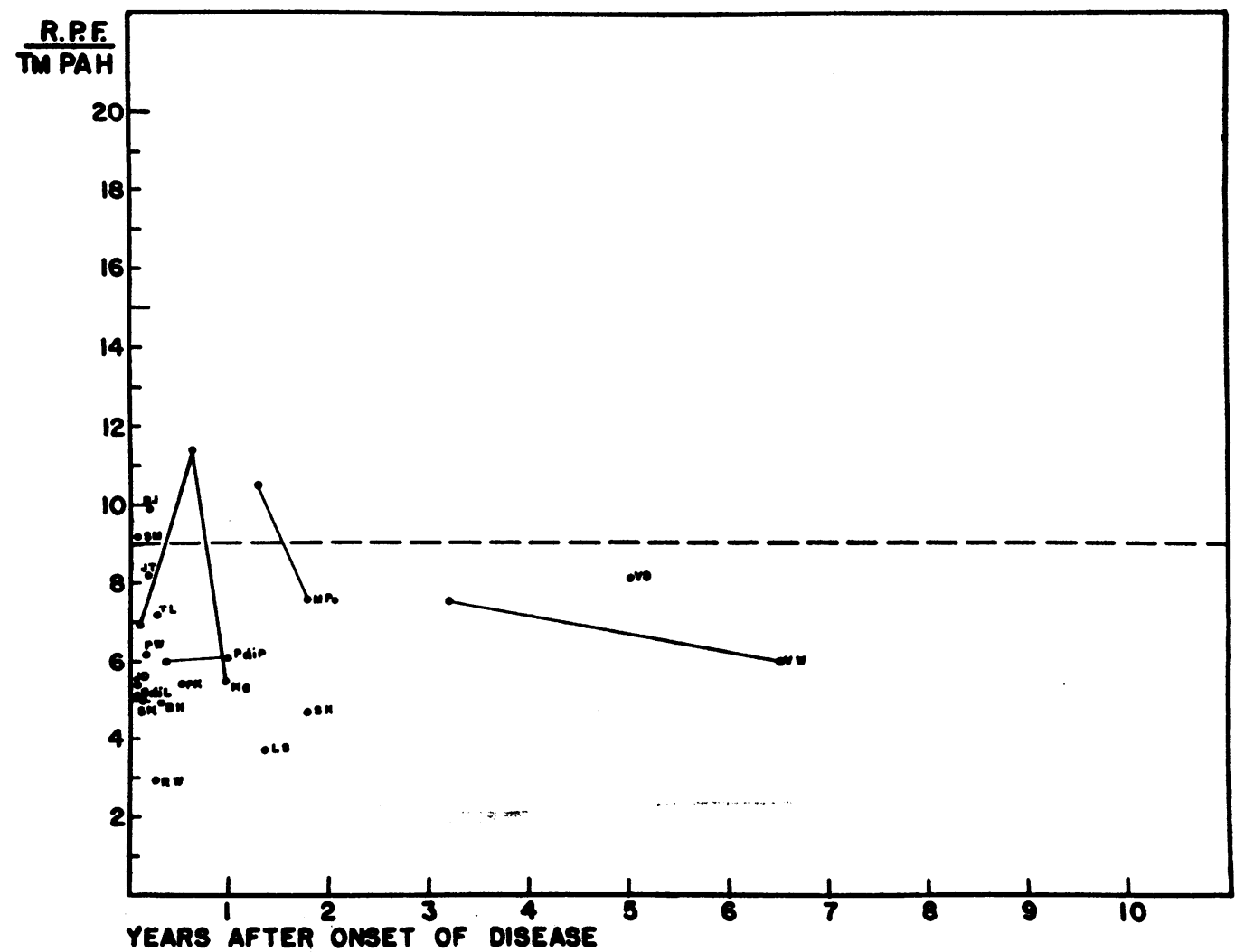

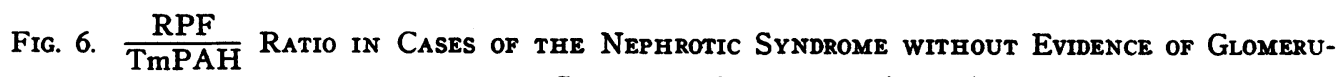
Symbols as in Figure 1. lonephritis, Group III, Case Nos. 25 to 45 


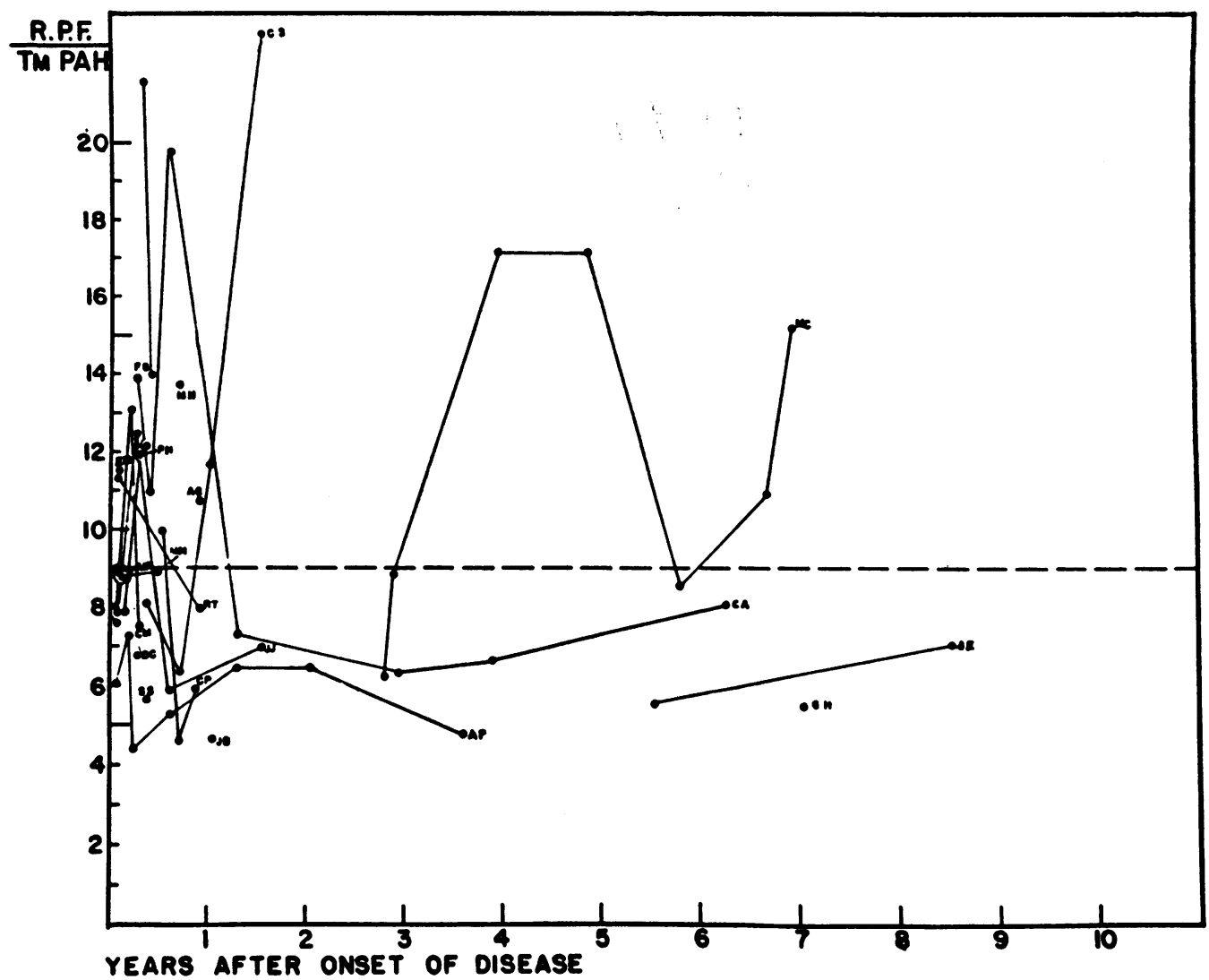

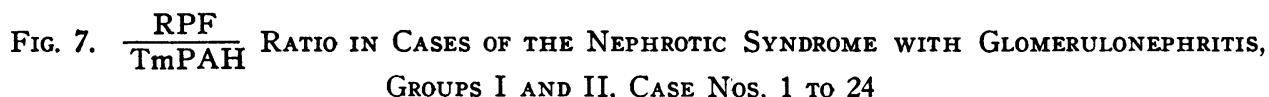

Symbols as in Figure 1.

F. Comparison of TmPAH with other tubular functions

The TmPAH, which presumably measures a function of the proximal tubules, may be compared with other signs indicating tubular impairment, such as isosthenuria, polyuria, and acidosis, although the mechanisms controlling acid excretion and water reabsorption against an osmotic gradient are considered to be localized in the distal tubules.

In Groups I and II there were 11 patients who at some time in their course had a TmPAH below $40 \mathrm{mg}$. per min. per $1.73 \mathrm{sq} . \mathrm{m}$. In two of these patients (C. A. and J. J.), this was a transient phenomenon. Of the other nine, eight died within a year, the ninth developed renal osteopathy and acidosis within the year following the clearance study. In Group III, two patients had a similarly low TmPAH during serious complications of the disease. One of these two, T. L., had a TmPAH of $25.6 \mathrm{mg}$. per min. per 1.73 sq.m. at the time when one of his kidneys was necrotic due to renal vein thrombosis.

Studies were not specially designed to test osmotic capacity or acid-excreting mechanisms; but from chemical study of the blood and observations of urine output and specific gravity (see Table I), it is evident that of ten patients with reduced TmPAH (not including the two patients in whom this occurred only transiently and the one with only one functioning kidney) four and probably a fifth had polyuria or polydipsia, four had isosthenuria or hyposthenuria, five and possibly a sixth had acidosis at the same time, and another one developed acidosis several months later. Taking into account the lack of precise information on these manifestations in many cases, it may be said that in general, reduction of the TmPAH seems to parallel evidence of distal tu- 


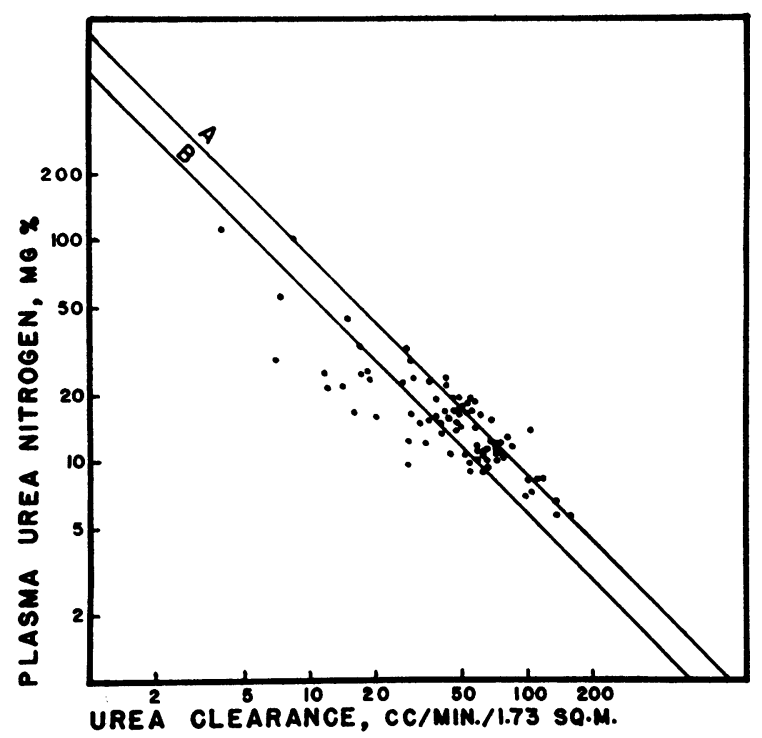

Fig. 8. Relation between Total Urea-N Output, Urea Clearance ( $\mathrm{CU}$ ) and Plasma Urea Nitrogen (BUN)

Each dot represents one test (average of three periods) in one of the patients. $\mathrm{Cu}$ and BUN are plotted logarithmically so that each of the diagonal lines represents a constant urea- $\mathrm{N}$ excretion, according to the equation: Total urea-N $=\mathrm{Cu} \times \mathrm{BUN}$. $\mathrm{Cu}$ and therefore total urea- $\mathrm{N}$ excretion figures are corrected for a surface area of 1.73 sq.m. Line A represents a urinary urea-N excretion of $12.8 \mathrm{Gm}$. per day per 1.73 sq.m., which would correspond to an intake of $125 \mathrm{Gm}$. of protein with a retention of $4 \mathrm{Gm}$. of $\mathrm{N}$ per day per $1.73 \mathrm{sq.m}$. (normal for infants and adolescents). Line $\mathrm{B}$ represents a urinary urea- $\mathrm{N}$ excretion of $8.3 \mathrm{Gm}$. per day per 1.73 sq.m., which would correspond to an intake of $90 \mathrm{Gm}$. of protein with a retention of $4 \mathrm{Gm}$. of $\mathrm{N}$ per day per 1.73 sq.m. (normal in middle childhood) or to an intake of $65 \mathrm{Gm}$. of protein with a zero $\mathrm{N}$ balance (adults). These figures are calculated with the assumption that 80 per cent of the total $\mathrm{N}$ excretion occurs in the urine as urea-N. Points below and to the left of the lines indicate a lower $\mathrm{N}$ excretion, i.e., lower protein intake or more positive balance; points above and to the right of the lines indicate a higher $N$ excretion, higher protein intake or less positive balance; e.g., with an average protein intake and $\mathrm{N}$ balance a child with a $\mathrm{Cu}$ of $30 \mathrm{cc}$. per min. per 1.73 sq.m. would be expected to have a BUN of $19 \mathrm{mg}$. per cent; however, there are children who with this $\mathrm{Cu}$ have a BUN of 9.5 or of 28 mg. per cent. A child with a $\mathrm{Cu}$ of $7 \mathrm{cc}$. per min. per 1.73 sq.m. would be expected to have a BUN of at least $83 \mathrm{mg}$. per cent; however, one child with such a low clearance had a BUN of $28 \mathrm{mg}$. per cent. Since many of the patients were bedridden and sick, one would expect a less positive $\mathrm{N}$ balance (higher output) than indicated in the lines. bular insufficiency and probably has similar prognostic implications.

\section{G. Fluctuation of clearance values}

From the foregoing discussion and from Figures 1,2 , and 3 and Tables I and II, it is evident that in several patients the GFR and TmPAH and also the ratios between the different functions showed considerable fluctuations during the course of illness and that transitory depression of functional capacity might be followed by striking improvement within a short time. In some patients such episodes of transient depression of GFR and TmPAH were associated with a recent intercurrent infection or with particularly severe anasarca and ascites. Caution seems to be indicated in evaluating tests done during or within a few weeks following complications of the nephrotic syndrome. Only repeated studies over prolonged periods may reveal the trend.

\section{H. Classification of patients}

The division of this case material into three categories may appear artificial, and in individual cases the classification into a particular group may initially be incorrect or impossible. The purpose of using the latest status known in each patient as a basis for classification was the hope of finding common characteristics in each group which could be related to the final pathological picture. Such characteristics might then be useful in attempts at predicting the prognosis of individual cases. Since the judicial use of modern antibiotics can prevent death from intercurrent infections, the prognosis of children with the nephrotic syndrome depends on the presence or absence and the rate of progression of inflammatory and hyalinizing glomerular lesions. After the disease has run its full course, it is usually possible to describe this course as following one of three patterns: 1) Relentless progression of glomerular, and eventually tubular, insufficiency with death within a few months or one to two years (Group I) ; or 2) lowgrade activity with long periods of latency and occasional exacerbations which may be compatible with normal growth and activity for several years and may occasionally last into adult life yet, in a high percentage of cases, will eventually result in death from renal insufficiency or hypertension 
(Group II) ; or 3) exacerbations and remissions of the nephrotic syndrome for several months or years with complete recovery and without permanent impairment of renal functions (Group III) (16). It would be of obvious advantage to the physician and the patient's parents to gain an indication of the probable future course early in the disease. From the studies here reported it appears that such indications may in many cases, though not in all, be obtained from a series of renal clearance tests, but not necessarily from a single test.

\section{CONCLUSIONS}

This series of 100 clearance tests in 45 children with the nephrotic syndrome permits the following conclusions: In spite of limitations in the interpretation of measurements taken in patients with diseased kidneys, it appears that common functional patterns may be distinguished in groups of patients with similar final outcome.

The glomerular filtration rate is frequently, though not uniformly, reduced in patients with the nephrotic syndrome who have, or will subsequently develop, evidence of glomerulonephritis. A rapidly progressive reduction in GFR is often the first indication of a rapidly fatal course. In patients who have a slow course with long periods of latent disease, the GFR and other functions may remain stationary, in proportion to the child's size, for several years, occasionally even at a supranormal level. Occasional fluctuations in this function in both directions may be observed.

The filtration fraction is reduced nearly consistently in patients with glomerulonephritis.

In patients with the nephrotic syndrome who never develop evidence of glomerulonephritis, the GFR and FF are usually normal or above normal but may be depressed transiently, particularly during or immediately following complications such as infections.

The TmPAH also may be temporarily depressed during complications but is usually normal or above normal in all cases of the nephrotic syndrome, with or without nephritis. Only in the terminal stages of nephritis a reduction of this function occurs roughly parallel with evidence of disturbance of distal tubular functions such as polyuria, isosthenuria, and acidosis.
The ratio $\frac{\text { GFR }}{\text { TmPAH }}$ is low in most patients with the nephrotic syndrome. Although this fact may be interpreted as indicative of a primary glomerular lesion in all cases of this syndrome, another explanation is suggested for certain cases; this ratio might also be low if there is an increase in tubular capacity above normal without corresponding increase of the GFR, but without actual damage to the glomerulus.

The ratio $\frac{\mathrm{RPF}}{\mathrm{TmPAH}}$ is within or below the normal range in the majority of patients. However, eight of the patients with evidence of glomerulonephritis had transient episodes with a very high $\frac{\mathrm{RPF}}{\mathrm{TmPAH}}$ ratio. It may be speculated that this high ratio indicates hyperemia and may be associated with inflammatory processes in the kidneys; however, the interpretation of this ratio in diseased kidneys is too uncertain to permit valid conclusions.

The urea clearance varied between 22 and 87 per cent of the mannitol clearance. Even in the same patient and at comparable urine flows the ratio of urea clearance to GFR was so variable that the urea clearance cannot be evaluated as a measure of GFR in these patients.

APPENDIX A

Criticism of methods used in the clearance studics

(A) Mannitol clearance: Comparison with imulin and creatinine clearance.

These studies were begun at a time when pyrogen-free inulin was not commercially available. Mannitol was, therefore, used for determination of the GFR and for the sake of consistency was kept in use after inulin was again available. Although, since 1947 , it has been pointed out repeatedly $(17,18)$ that the ratio $C_{M} / C_{I}$ is closer to 0.9 than 1.0, this deviation from the inulin clearance seems to be minimal with the method for mannitol determination which was used in the present study ${ }^{4}$ (12). In five cases where both inulin and mannitol clearances were determined, the average $C_{M} / C_{1}$ ratio was found to be 0.95 with a range from 0.85 to 1.02 (see Table IV). Earle, Taggart, and Shannon (7), using the same mannitol method but a different inulin method, found an average $\mathrm{C}_{M} / \mathrm{C}_{\mathrm{I}}$ ratio of 0.96 in eight patients with glomerulone-

4 This method involves yeasting of plasma and urine samples followed by periodate oxidation without the use of heat. 
phritis. If the inulin clearance is accepted as a measure of the glomerular filtration rate, the mannitol clearance may also be considered to provicle a close enough approximation of this measure for the purpose of evaluating the status of glomerular function in a patient. However, a falsely low figure for the GFR will result in calculation of a falsely high TmPAH; this error will be exaggerated if the TmPAH is low and the load of PAH high. Table IV shows that in most patients with the nephrotic syndrome the endogenous creatinine clearance is much higher than the inulin and mannitol clearances and can therefore not be used as a measure of the (iFR. This has also been observed by others (5).

\section{(B) Clearance and extraction of $P A H$}

The use of the clearance of PAH as a measurement of the effective renal plasma flow in patients with renal disease is subject to fundamental criticism. The $\mathrm{C}_{\mathbf{P A H}}$ measures renal plasma flow only under the condition that $\mathrm{PAH}$ is completely extracted from the blood within one circulation through the kidney. Earle, Taggart, and Shannon (7) assumed on the basis of their Diodrast ${ }^{\circledR}$ titration studies that the extraction in renal disease is essentially complete until the TmD falls below a certain level, about 10 per cent of its normal value, or unless the ratio of load/TmD exceeds 0.5 . However, other workers (8) have demonstrated that the extraction ratio in the nephrotic syndrome in the terminal phase of chronic glomerulonephritis and even in acute glomerulonephritis, may vary from 47 to 100 per cent even without extreme reduction of the TmPAH. These authors note that the extraction ratio may vary in the same patient, at different times, not always in the same direction as TmPAH. According to Bradley's observations as well as theoretical considerations $(11,12,21)$ no definite extraction ratio may be assumed for a specific diseased kidney without being actually determined, although Cargill (22) states that in his patients the extraction did not seem to decrease until the inulin clearance had fallen below $60 \mathrm{cc}$. per min. and the PAH clearance below $300 \mathrm{cc}$. per min. Since the extraction ratio was not determined in our patients, no attempt has been made to correct the RPF figures for incomplete extraction. Under these circumstances, the determinations of the $C_{\mathrm{PAH}}$ can only be evaluated with reservations. However, since the error in calculating the RPF will always be in the downward direction, a $\mathrm{RPF}$ or $\frac{\mathrm{RPF}}{\mathrm{TmPAH}}$ ratio found high and a FF found low will still be significant. In the studies here reported, the maximal plasma level of $\mathrm{PAH}$ was below $2.0 \mathrm{mg}$. per $100 \mathrm{cc}$. in 51 tests, between 2.01 and 3.0 in 21 tests, between 3.01 and 4.0 in 11 tests " and between 4.01 and 5.0 in 3 tests. ${ }^{6}$

(C) Conjugation of PAH in the kidney

Conjugated $\mathrm{PAH}$ in plasma and urine was determined in 36 periods in 13 tests. There was no evidence of conjugation of $\mathrm{PAH}$ in the kidney, and the clearances of free $\mathrm{PAH}$ were essentially identical with those of total $\mathrm{PAH}$.

(D) Effect of glucose infusion on apparent cliarance of
P.AH

Because of the tendency of nephrotic children to retain salt, PAH for infusions was usually given in 5 per cent glucose solution in water. Other workers in the field

"F. Mc., second test; P. H., second test; A. G., first test; M. C., eighth and ninth tests; C. A., fourth and eighth tests; A. P., sixth and seventh tests: P. K. and S. K.

"M. Pe., second test: S. B. and M. C., seventh test.

TABLE IN

Comparison of clearances of mannitol, inulin, and creatinine in children with chronic renal disease*

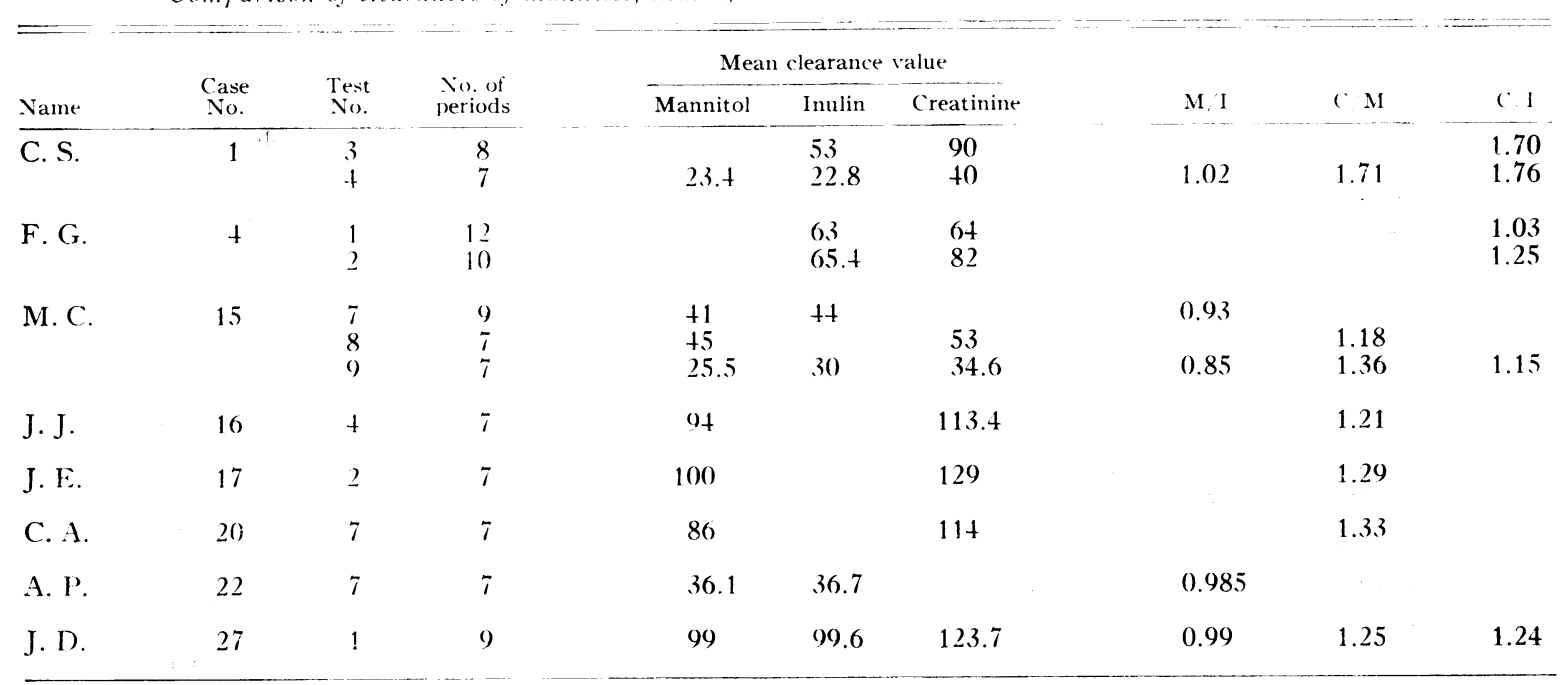

* Inulin was determined with the method of Hubbard and Loomis (19), modified by using Harrison's acid hydrolysis mixture (20). 
TABLE $V$

Distribution of Mannitol and PAH in body fluids

\begin{tabular}{|c|c|c|c|c|c|c|c|c|c|c|}
\hline \multirow[b]{2}{*}{ Name } & \multirow[b]{2}{*}{ No. } & \multirow{2}{*}{$\begin{array}{c}\text { Time } \\
\text { after } \\
\text { injection }\end{array}$} & \multirow{2}{*}{$\begin{array}{c}\text { Body weight } \\
\text { with } \\
\text { ascites }\end{array}$} & \multirow{2}{*}{$\begin{array}{l}\text { Amt. of } \\
\text { fluid } \\
\text { obtained }\end{array}$} & \multicolumn{3}{|c|}{$\begin{array}{c}\text { Mannitol level } \\
m g . / 100 ~ c c .\end{array}$} & \multicolumn{3}{|c|}{$\begin{array}{l}\text { PAH level } \\
m g . / 100 c c .\end{array}$} \\
\hline & & & & & Blood & $\begin{array}{l}\text { Ascitic } \\
\text { fluidt }\end{array}$ & A/B & Blood & $\begin{array}{l}\text { Ascitic } \\
\text { fluid }\end{array}$ & A/B \\
\hline $\begin{array}{l}\text { C. P. } \\
\text { J. M. } \\
\text { L. P. } \\
\text { J. J. } \\
\text { P. K. }\end{array}$ & $\begin{array}{r}5 \\
41 \\
13 \\
16 \\
29\end{array}$ & $\begin{array}{c}\min . \\
65 \\
72 \\
74 \\
76 \\
80\end{array}$ & $\begin{array}{l}K g . \\
19 \\
22.3 \\
24.5 \\
16 \\
17\end{array}$ & $\begin{array}{c}c c . \\
? \\
? \\
470^{*} \\
1600 \\
2150\end{array}$ & $\begin{array}{c}106.5 \\
90 \\
107 \\
116 \\
67.5\end{array}$ & $\begin{array}{l}79.6 \\
56 \\
48^{*} \\
50 \\
54.5\end{array}$ & $\begin{array}{l}0.75 \\
0.62 \\
0.45 \\
0.43 \\
0.81\end{array}$ & $\begin{array}{l}1.08 \\
-1.19 \\
1.25 \\
2.80\end{array}$ & $\begin{array}{l}1.04 \\
\overline{1.03} \\
0.59 \\
0.83\end{array}$ & $\begin{array}{l}0.47 \\
0.47 \\
0.30\end{array}$ \\
\hline
\end{tabular}

* Pleural fluid.

† Obtained during clearance procedure.

(23) in 1950 reported depression of the apparent extraction and clearance of $\mathrm{PAH}$ when the $\mathrm{PAH}$ was given with glucose solution. They demonstrated that this error is due to an in vitro conjugation of $\mathrm{PAH}$ with glucose before infusion, and to the fact that the conjugation product, which has a low clearance and, therefore, does not appear in the urine, dissociates under the influence of the acid used in the determination of the plasma level of PAH. Therefore, the plasma level determined will be total $\mathrm{PAH}$ while the urine contains only free $\mathrm{PAH}$. These authors point out that the time during which $\mathrm{PAH}$ and glucose are in contact before being infused is an important factor in the formation of the conjugation product and thereby in the production of a false low clearance. In the tests here reported, the solution was always prepared immediately before use; the time from the preparation of the solution to the end of the infusion was never more than two hours, either for the clearance at low plasma levels or the determination of TmPAH. Discoloration of the solution was never noted. It is, therefore, believed that false depression of $\mathrm{PAH}$ clearance by this mechanism was rare and minimal.

\section{(E) Calculation of surface area}

In edematous patients in whom calculation of the surface area from the weight would have given erroneously high values, the weight before the development of edema was used for the calculation whenever it could be ascertained; in other cases the lowest weight attained during the hospital stay was taken as the standard, neglecting normal development within a few weeks or months. The lowest weight in some cases still included edema fluid.

We were unable to estimate the extent of edema in order to obtain more reliable "dry weight" for the calculation of surface area. Table $\mathrm{V}$ shows the lack of equilibration of mannitol or $\mathrm{PAH}$ between the plasma and effusion fluid over a period of 65 to 80 minutes, after the time usually allotted for plasma equilibration. Thus "extracellular fluid space" could not be calculated from the distribution of these substances. On the other hand, one might argue that the "dry" weight (and the surface area calculated from it) in a malnourished or cachectic patient does not necessarily bear a relation to his kidney function, as a patient may lose fat, muscle tissue, and water without influencing his functioning kidney tissue. Therefore, the calculation of the surface area, and of the kidney functions in relation to it, is not strictly accurate in many patients with severe renal disease; however, in no case was the error probably large enough to invalidate the interpretation of the functional data obtained (see "Remarks" in Appendixes B and C).

APPENDIX B

Remarks and clinical observations related to the data in Table I

\begin{tabular}{|c|c|c|}
\hline $\begin{array}{l}\text { Case } \\
\text { No. }\end{array}$ & $\begin{array}{l}\text { Duration } \\
\text { of illness }\end{array}$ & \\
\hline 1 & $\begin{array}{l}4 \mathrm{mo} . \\
8 \mathrm{mo} . \\
12 \mathrm{mo} . \\
18 \mathrm{mo} .\end{array}$ & $\begin{array}{l}\text { Patient supposedly had sinusitis } 2 \text { months previously after onset of peri-orbital edema. } \\
\text { N.P. and throat cultures: Staph. and pneumoc. Sed. rate } 52 \mathrm{~mm} \text {. } \\
\text { Recurrent edema. Receiving plasma infusions. Same S.A. correction as on previous test. } \\
\text { Poorly checking test. Child appearing progressively malnourished. Had several infections } \\
\text { during last } 2 \text { to } 3 \text { months. } \\
\text { S.A. calculated from lowest weight. Has had acidosis for last } 4 \text { to } 5 \text { months. Acidosis } \\
\text { became severe during the } 2 \text { months following this test (CO } 8.6 \text { to } 4.6) \text {, requiring continuous } \\
\text { alkali therapy. P elevated for last } 4 \text { mo., Ca falling to minimum of } 4.2 \text { two months after } \\
\text { this test, with manifestations of tetany. Nephrotic episode continuous from onset at } 7 \frac{1}{2} \text { y. } \\
\text { to death at } 9 \frac{1}{2} \text { y. Autopsy: "Typical picture of chronic diffuse glomerulo-nephritis. Bulk } \\
\text { of the glomeruli hyalinized. Hyperplasia of two parathyroid glands. Atheromatosis of } \\
\text { aorta. Hyaline membranes in lungs." }\end{array}$ \\
\hline
\end{tabular}




\begin{tabular}{cc}
$\begin{array}{c}\text { Case } \\
\text { No. }\end{array}$ & $\begin{array}{c}\text { Duration } \\
\text { of illness }\end{array}$ \\
\hline 2 & 2 wks. \\
& 3 mo.
\end{tabular}

Nephrotic syndrome. Had one bout of transitory gross hematuria before admission to hospital. Receiving penicillin.

PAH determinations spoiled by attempts to defat plasma. P.F. probably unreliable, Tm calculation gave negative results. Same $S$.A. correction used as on previous test. Patient showed marked nephrotic syndrome with increasing hypertension, changes in EKG and in retinal arteries. Two to three months after this observation, patient lost all edema, was emaciated, died of renal insufficiency at $7 \frac{1}{2} \mathrm{y}$.

$3 \quad 1$ mo.

5 mo.

$4 \quad 3 \mathrm{mo}$

4 mo.

8 mo.

$10 \mathrm{mo}$.
Nephrotic syndrome. On Duracillin therapy for respir. infection (culture: Staph.). Had T \& A 7 months previously, no urinalysis recorded. S.A. calculated from "ideal weight." Same S.A. correction used as on previous test. Receiving serum albumin for 3 days, one infusion just finished before clearance test. Also on penicillin (not during test). Patient died with signs suggestive of pulmonary embolus 5 weeks later, no autopsy. During last month hypertension and anemia were prominent.

Nephrotic syndrome, just got over infection. S.A. calculated from lowest weight in hospital. Same S.A. correction used as on previous test. After course of ACTH. Patient died 6 weeks after this test at home, no autopsy.

Had peritonitis (? Staph.) 1 week ago, just recovered.

All values in this test are probably falsely low because of technical error in defatting plasma. 1 y. later readmitted, progressive renal failure (NPN \& P rising, Ca falling). No hypertension. Spent a year in hosp., died at $75 / 12$ y. Autopsy: white, contracted kidneys (130 $\mathrm{Gm}$.) with multiple subcapsular hemorrhages, completely distorted architecture. Many glomeruli had disappeared.

"Ideal weight" was used for calculation of S.A. of this very edematous patient. Died of uremia 1 to $2 \mathrm{y}$. later in another city.

Patient admitted on surgical service for hernia operation; nephrotic syndrome diagnosed by surgical interne, but patient went home untreated. Numerous urines neg. for alb., all alkaline.

Increasing edema for 5 months. Subsequent to this test, patient had 2 admissions, each time for massive edema which each time responded to serum albumin. Had intercurrent U.R.I.'s (staph. aur.) and, on one occasion, heart failure. Minimum weight $35 \mathrm{lbs} .12$ days after test (following serum alb.). This weight used for calculation of S.A.

On urea therapy. Last seen 1 month hereafter, with massive edema.

Nephrotic syndrome following respir. infection 1 month previously. Throat culture: pneumoc. Penicillin started 3 days before test. S.A. based on weight before onset of edema, 2 weeks previous to test.

Acute otitis media (staph.).

Weight includes ascites but is only $1 \frac{1}{2}$ lbs. more than before onset of disease. Getting thyroid grs. iiss daily, for past $3 \mathrm{wks}$. $\frac{\operatorname{load}(\mathrm{PAH})}{\mathrm{T} \text { PAH }}$ during P.F. determination $=0.36$; but complete extraction of PAH cannot be assumed for this kidney. Patient had 4 to 5 paracenteses in 7 to 8 months. Developed acidosis, severe hypocalcemia and osteoporosis, severe anemia. Died 6 mo. after this test, no autopsy.

Very obese patient. Mother dates edema 1 mo. before observation. Three urinalyses at C.H. at ages 7, 8, 9 were normal. Clearance figures not quite certain since weight without

edema unknown; S.A. correction based on weight incl. edema. Sed. r. 45 .
Weighs 19 lbs. less than during previous test, therefore S.A. correction 3 to + per cent higher. Weighs another 20 lbs. less; S.A. correction now 10 per cent higher than on first observation. Patient died of uremia at $1311 / 12 \mathrm{y}$. in another hospital.

Sudden onset of edema, abdominal pain, transitory hematuria, rapidly changing hypertension. Was first suspected to have acute glomerulonephritis, but nephrotic syndrome soon increased in severity and persisted. S.A. calculated from lowest weight in hospital, 10 days after this test. Poor check between periods of PAH clearance.

Treated with large amounts of salt-free serum albumin. Same S.A. correction used as on previous test.

Same S.A. correction used as before. Still had active disease at age $8 \mathrm{y}$., with edema, hypertension, and mild azotemia. Reported in Corticotropin study by Rapoport et al. (5).

Complete extraction of PAH cannot be expected in this kidney. Died of cardiovascular failure. Same S.A. used as on last test. Sed. r. 22. 
APPĖNDIX B-Continued

$\begin{array}{ll}\text { Case } & \begin{array}{l}\text { Duration } \\ \text { of illness }\end{array} \\ \text { No. } & \text { of }\end{array}$

12

4 mo.

14 mo.

1 wk.

9 mo.

33 mo.

34 mo.

45 mo.

$58 \mathrm{mo}$.

$66 \mathrm{mo}$.

69 mo.

83 mo.

87 mo.

1 wk.

2 mo.

7 mo.

$17 \mathrm{mo}$.

$5.5 \mathrm{y}$

$8.5 \mathrm{y}$.
Severe nephrotic syndrome; diuresis started 1 week before clearance test, following abdominal paracentesis. Lost 30 per cent of his weight in 7 days. S.A. based on weight incl. $1+$ edema. Had recurrence of severe nephrotic syndrome 6 wks. later, lasting for 26 months, requiring many paracenteses. Microscopic hematuria and pyuria constant, mild azotemia, normal B.P. Then had spontaneous diuresis, 1 month later modified measles, followed by complete remission except for albuminuria, 1 to $2+$. Eleven months after measles had tonsillectomy, thereafter recurrent nephrotic episode with hypertension and rapid downhill course. Died of uremia at 5 10/12 y. Autopsy: chronic glomerulonephritis.

This patient had had anuria for 2 days and questionable hematuria 8 months before admission, intermittent but generally increasing edema since then. Severe nephrotic syndrome (weight 60 per cent more than before illness) and rapidly increasing hypertension. Persistent serum calcium of $3.5 \mathrm{mg}$. per cent.

S.A. was calculated for weight during an edema-free period 2 months prior to this test (32 lbs.). Quotient $\frac{\text { load (PAH) }}{\text { TmPAH }}$ for plasma flow determination periods was 0.115 . Nevertheless, complete extraction of PAH by this kidney is to be doubted. Patient died of hypertensive encephalopathy 8 days later. Autopsy: diffuse subacute hemorrhagic nephritis with very marked nephrotic swelling.

Patient had what appeared to be acute nephritis complicating scarlet fever 4 months prior to this observation, then passed into nephrotic stage.

1 y. later patient clinically well, B.P. $122 / 74$ but albuminuria between trace and + and occ.

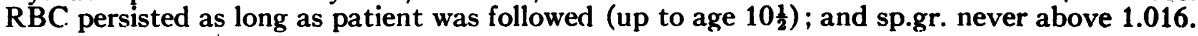

History of gross hematuria 1 wk., no other signs or symptoms. Albuminuria and microscopic hematuria persisted.

2nd admission for study. Still asymptomatic. PSP 85 per cent in 2 hrs. Hemol. Strep. in throat.

Slight puffiness of eyes for 3 months.

Just got over mild scarlet fever.

Has been on prophyl. sulfadiazine for 9 months. No U.R.I.'s since then. Attending public school regularly.

2 to 3 very mild U.R.I.'s in a year. Still on prophyl. sulfa.

Puffy eyelids, pallor, growth slowing down, listlessness. Sent to convalescent home 1 month later. Taken off sulfa by outside M.D., bedrest 3 months.

Improved, exc. slight pretibial edema. Two mo. later had several U.R.I.'s, started on prophyl. sulfa again. Attempt at salt-poor, high protein diet.

Has been in bed with high-protein diet (poorly taken) and without sulfa for 3 months; condition essentially unchanged.

Up and around, restricted activity, no sulfa. Tm not done because patient had shown severe reaction to PAH on previous test. TmPAH must be assumed to have decreased further since last test. PAH level for $\mathrm{C}_{\mathrm{PAH}}$ was $4 \mathrm{mg}$. per cent, extraction probably low, therefore, figure for P.F. falsely low. Patient died at age 13 8/12 y. Hypertension, heart failure, hyperpotassemia. No autopsy.

Frequent U.R.I., cultures staph. and pneumoc. Sudden onset of edema. S.A. calculated from lowest weight in hosp. which still included edema. Sed. r. 49.

Marked increase of edema and ascites. Ascites tapped during test, 70 minutes after priming injection. Mannitol level $=43$ per cent of plasma level, PAH level $=47$ per cent of plasma level. Same S.A. correction used as on previous test.

On strict salt-free diet and thyroid extract for 4 months. Edema and ascites disappeared 3 months ago. Sed. r. 7.

Asymptomatic. Developing normally. Thyroid discontinued 6 months ago. Sed. r. 5.

Patient was very ill for 1 year with numerous infections (respiratory, skin, urinary, blood stream), incl. septicemia and peritonitis due to pneumococcus type 19; treated with sulfadiazine, plasma, hypertonic glucose, digitalis, liver extr. Many RBC seen in every urine spec. during that year. Thereafter gradually improved; not seen between age $5 \frac{1}{2}$ and 9 . Asymptomatic. Urine tested for alb. regularly by mother; remained neg. until age $12.0 \mathrm{y}$. Two routine analyses in hosp. at age 11 showed alb. negative.

Albuminuria discovered again 3 mo. before test. Fatigue and trace edema 2 mo. before test,

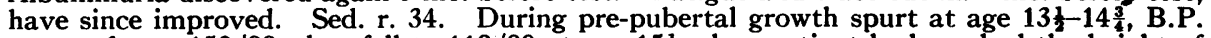
rose as far as $152 / 88$, then fell to $118 / 80$ at age $15 \frac{1}{4}$ when patient had reached the height of 70 inches. Albuminuria $1+$ to $2+$ persisted, RBC "rare" in routine specimens, none seen after age $14 \frac{1}{2}$. No edema, no complaints for last $3 \frac{1}{2}$ years.

Only complaint: recurrent edema (face and legs). Sed. r. 37.

Hemol. strep. in throat. 


\begin{tabular}{|c|c|c|}
\hline $\begin{array}{l}\text { Case } \\
\text { No. }\end{array}$ & $\begin{array}{l}\text { Duration } \\
\text { of illness }\end{array}$ & \\
\hline 19 & $\begin{array}{l}\text { age } 10 \\
\text { age } 10.8 \\
\text { age } 12.3\end{array}$ & $\begin{array}{l}\text { Pharyngitis (frequent), culture: staph. aur. Albuminuria found on routine urinalysis. } \\
\text { large tonsils. Pyelograms normal. No symptoms of renal disease. } \\
\text { Asymptomatic. Tonsils have shrunken. At Convalescent Home. } \\
\text { Still asymptomatic. At home without therapy. Sed. r. } 9 \text {. }\end{array}$ \\
\hline 20 & $\begin{array}{l}+\mathrm{mo} \text {. } \\
6 \mathrm{mo} \text {. } \\
7 \mathrm{mo} \text {. } \\
7.5 \mathrm{mo} \text {. }\end{array}$ & $\begin{array}{l}\text { History: frequent tonsillitis, T \& A age } 6 \text {, mild edema, pallor, anorexia, occasional vomiting } \\
\text { for } 3 \text { mo. Sed. } 63 \text {. Severe reaction (fever, hypertension, abdom. pain, rise of NPN) to } \\
\text { i.v. Diodrast. Therapy: urea for diuresis, lost } 2 \mathrm{Kg} \text {., blood and plasma transfusions. Re- } \\
\text { pair and extraction of teeth. } \\
\text { High protein, high vitamin, low salt diet. Went home, to school, rode bicycle, etc. Sed. r. } \\
27 \text {. } \\
\text { Chronically ill, pale, tired, trace edema, } \mathrm{Hgb} .9 .0 \mathrm{Gm} \text {. per cent, sed. r. } 67 \text {. Sent to conva- } \\
\text { lescent home, bedrest, iron therapy. } \\
\text { Fever } 105 \text { three days previously, cause unknown, prompt response to penicillin. Hgb. } 9.0 \\
\text { to } 6.0 \mathrm{Gm} \text {. per cent, sed. r. } 55 \text {. } \\
\text { Had blood transfusions, total } 1000 \text { cc., Hgb. } 13.0 \mathrm{Gm} \text {. per cent. Bedrest } 4 \text { months after } \\
\text { this, then very gradual increase of activity. Feosol discontinued, appetite and Hgb. im- } \\
\text { proved within } 4 \text { to } 6 \text { months, gained height and weight. } \\
\text { Still at convalescent home, Hgb. } 12.5 \mathrm{Gm} \text { per cent. } \\
\text { Discharged from convalescent home. Full activity, except for gym, etc. Growing fast. } \\
\text { U.R.I. Started prophyl. sulfadiazine. } \\
\text { Asymptomatic. Growing well. No U.R.I.s. Started menstruating at } 109 / 12 \mathrm{y} \text {. Sed. r. } \\
24 \text {. } \\
\text { Asymptomatic, but Hgb. } 8.9 \mathrm{Gm} \text {. per cent. } \\
\text { Asymptomatic. Fully developed. Condition still unchanged at age } 15 \mathrm{y} \text {. }\end{array}$ \\
\hline 21 & 3 wks. & $\begin{array}{l}\text { Had ascites and edema, occ. hematuria. Supposed to have had ear infection, possibly scarlet } \\
\text { fever, preceding his illness. Treated with sulfapyridine for peritonitis (no cultures). PSP } \\
40 \text { per cent } / 2 \text { hrs. Was kept in bed at home for } 2 \text { years following this episode. Supposedly } \\
\text { had no albuminuria thereafter. (?) } \\
\text { Albuminuria started again following (?) German measles. Interval observation very un- } \\
\text { reliable. Patient complaining of headache. Sed. r. 35. } \\
\text { Patient feeling well at age } 15 \text { (telephone report). }\end{array}$ \\
\hline 22 & $\begin{array}{l}24 \mathrm{mo} \text {. } \\
43 \mathrm{mo} \text {. } \\
56 \mathrm{mo}\end{array}$ & $\begin{array}{l}\text { This patient was admitted for mild U.R.I. Albuminuria and other abnormal findings found } \\
\text { on routine urinalysis. Patient never had any clinical symptoms (exc. running nose); on } \\
\text { cystoscopy papilloma of bladder was seen but disappeared later on. Pyelograms normal. } \\
\text { Sed. r. } 50 \text {. } \\
\text { Biopsy for periarteritis nodosa negative (quadriceps). Sed. r. } 56 \text {. } \\
\text { Had blood transfusion } 4 \text { days ago. Hgb. } 13.8 \mathrm{Gm} \text {. per cent, sed. r. } 44 \text {. } \\
\text { Just got over impetigo. Cultures: skin-strep. and staph., N-P: staph. aur. Treated with } \\
\text { penicillin, good response. No fever. Patient had eosinophilia ( } 6 \text { to } 18 \text { per cent) from age } \\
3.0 \text { to } 38 / 12 \text { y., no cause found. Sed. r. } 52 \text {. } \\
\text { Still asymptomatic. Well developed. Spent almost the entire } 2 \text { years at convalescent home. } \\
\text { Liver slightly enlarged as long as patient has been known in this hospital. Sed. r. } 47 \text {. Still } \\
\text { Very slight edema; this disappeared again a month later while hypertension persisted. Still } \\
\text { growing normally. Sed. r. 50. } \\
\text { During the last } 5 \text { months, B.P. has risen steeply; child, for the first time in her course, has } \\
\text { been looking chronically ill, yellowish-pale, but has had no complaints. Hgb. fell to a low } \\
\text { of } 7.5 \text { Gm. per cent, then, with iron therapy, rose again to present level. No weight gain } \\
\text { in a year, growth slowing down. Due to low TmPAH, plasma flow could not be determined } \\
\text { at this time. } \\
\text { Patient died at } 69 / 12 \text { y. of age with uremia. No autopsy. }\end{array}$ \\
\hline 23 & $5 \mathrm{y}$. & $\begin{array}{l}\text { Had nephrotic syndrome } 4 \text { years previously; at present hypertension with mild cardiac } \\
\text { enlargement predominant sign. Sed. } r \text {. } 25 \text {. } \\
\text { PAH load too high to calculate plasma flow. } \\
1 \text { y. later developed renal osteitis fibrosa and marked hypertension. Still alive (adm. to } \\
\text { hosp.) at age } 18 \mathrm{y} \text {. }\end{array}$ \\
\hline 24 & $8 \mathrm{y}$. & $\begin{array}{l}\text { Patient had nephrotic syndrome (in other hospital) } 7 \frac{1}{2} \text { yrs. previously. Had had few RBC } \\
\text { in urine and B.P. } 144 / 102-118 / 85 \text {. Was then asvmptomatic until about } 1 \mathrm{mo} \text {. before present } \\
\text { adm. At present polyuria, headache, heart failure. Urine culture: Staph. aur. Hyper- } \\
\text { tensive retinopathy. Patient also had urethral stricture, but retrograde pyelograms neg. } \\
\text { Mild acidosis: CO.2 } 18.4 \mathrm{mEq} \text {. per L., Ca } 7.9 \mathrm{mg} \text {. per cent, P } 10.7 \mathrm{mg} \text {. per cent. } \\
\text { Died of hypertension and heart failure, having developed acidosis, hypocalcemia }(5.3 \mathrm{mg} \text {. } \\
\text { per cent) and heart failure during last } 2 \text { months. No autopsy. }\end{array}$ \\
\hline
\end{tabular}


APPENDIX C

Remarks and clinical observations related to the data in Table II

\begin{tabular}{|c|c|c|}
\hline $\begin{array}{l}\text { Case } \\
\text { No. }\end{array}$ & $\begin{array}{l}\text { Duration } \\
\text { of illness }\end{array}$ & \\
\hline 25 & & $\begin{array}{l}\text { Patient had onset of edema } 3 \text { months prior to this observation. } 10 \text { days before test he was } \\
\text { very severely ill with probable peritonitis and pneumonia and myocardial damage (EKG). } \\
\text { Treated with penicillin, streptomycin, paracentesis, blood and plasma infusions, digitalis. } \\
\text { Plasma and penicillin being continued up to time of clearance test; patient much improved. } \\
\text { S.A. calculated from weight before illness. Died } 17 \text { months later of pneumococcus peritonitis. } \\
\text { Autopsy: large, swollen kidneys, histological picture of "lipoid nephrosis," architecture intact. }\end{array}$ \\
\hline 26 & & $\begin{array}{l}\text { Marked nephrotic syndrome. Treated with penicillin for U.R.I. (culture Staph. aur.), but } \\
\text { not on day of test. Went home after this test, returned } 5 \text { months later, died of E. coli perito- } \\
\text { nitis. Autopsy: lipoid nephrosis and "interstitial (septicemic) nephritis, no evidence of } \\
\text { glomerular pathology, recent or old." }\end{array}$ \\
\hline
\end{tabular}

For 3 months following this test patient had intermittent mild, then suddenly severe edema, followed by complete diuresis. Hospitalized elsewhere with another episode of edema, 5 to 7 mo. after test, then well. Seen here again at age $511 / 12$, completely well, incl. urinalysis. Still well at age $7 \frac{1}{2}$.

Mild nephrotic syndrome, on Duracillin.

Had massive anasarca and ascites 4 mo. previous to this test, weighed 65 per cent above minimal weight. Then had complete diuresis. Present episode initiated with jaundice (apparently infectious or serum hepatitis). $2150 \mathrm{cc}$. ascites removed during test. S.A. calculated from weight after removal of ascites. Had microscopic hematuria on many occasions, but always slight. Recovered, well at age of $8 \mathrm{y}$.

Mild nephrosis. History resembled course of acute glomerulonephritis, urine supposed to have been brown at home, but no RBC found in hospital. (No Addis count done.) Patient recovered, well at age of $7 \mathrm{y}$.

Patient had nephrotic syndrome with massive anasarca, weighing 50 per cent more than present weight, 12 days ago. Had measles followed by rapid diuresis and subsidence of albuminuria (from ++++ to $t r$.).

$32 \quad 38 \mathrm{mo}$.

$78 \mathrm{mo}$.

$11 \mathrm{mo}$.

Second episode of mild nephrotic syndrome; static for about $1 \mathrm{y}$. after being asymptomatic for $1 \mathrm{y}$.

Asymptomatic. Urinalysis still neg. $1 \mathrm{y}$. after this observation.

Mild nephrotic in latent stage. No follow-up.

Fourth hospital adm. for nephrotic syndrome; at present asymptomatic. Sed. r. 25/30 min. Had pneumoc. peritonitis 9 mo. previously. Had recurrent edema for $1 \mathrm{y}$. after this test, then edema-free and clinically well for 5 yrs. with normal BUN, serum proteins and cholesterol, but persistent albuminuria.

Mild nephrosis.

1 y. later condition unchanged.

Marked nephrotic syndrome. Got well within next year, followed for $6 \frac{1}{2} \mathrm{y}$.

2 mo. Severe nephrotic, no infection. Sed. r. 66. S.A. calculated from weight without edema, 1 mo. later.

3 mo. - Patient had developed sudden anemia, mass in one side of abdomen, anorexia, hematuria and azotemia 21 days before test. Died 4 days later; autopsy showed thrombosis of inf. vena cava, left renal and right adrenal and both femoral veins with necrosis of one kidney.

Severe nephrotic syndrome. Treated with concentrated human albumin for 14 weeks in previous hospital. Sed. r. 22. At time of test weight was 40 per cent above minimum wt. which was reached 7 days later by sudden diuresis. S.A. calculated from minimum weight in the hospital.

New bout of nephrosis, sed. r. 28; again had same weight curve as on 1st adm., diuresis started 5 days after test, following plasma transfusions. S.A. calculated from weight after diuresis, 11 days later.

Nephrotic without complications. Got first dose of human serum albumin previous day. Lost 5 lbs. in last 24 hours. S.A. calculated from minimum weight of $42 \mathrm{lbs}$., reached after diuresis 2 weeks later.

2 yrs. later patient suddenly died at home, no autopsy. 
APPENDIX C--Continued

\begin{tabular}{|c|c|c|}
\hline $\begin{array}{l}\text { Case } \\
\text { No. }\end{array}$ & $\begin{array}{l}\text { Duration } \\
\text { of illness }\end{array}$ & \\
\hline 40 & & $\begin{array}{l}\text { Mild nephrotic syndrome, patient ambulatory at time of test. Tubules not saturated with } \\
\text { PAH for Tm determination, } 145 \mathrm{mg} \text {. represents entire load. } 1 \mathrm{y} \text {. later bronchopneum.; lab. } \\
\text { signs of nephrosis still present, no edema. } \\
\text { Subsequently recovered, well at age of } 9 \mathrm{y} \text {. }\end{array}$ \\
\hline 41 & $\begin{array}{l}9 \text { days } \\
4 \text { mo. } \\
7 \text { mo. }\end{array}$ & $\begin{array}{l}\text { Severe nephrotic syndrome, no complications. Minimum weight in hosp. } 34 \text { lbs. S.A. cal- } \\
\text { culated from this lowest weight. } \\
\text { Ascites tapped during test. } \\
\text { Spoiled by extreme lipemia and attempts at defatting plasma. Enreliable. Same S.A. } \\
\text { correction used as on previous tests. } \\
1 \text { y. later completely well, incl. urinalysis. }\end{array}$ \\
\hline 42 & & $\begin{array}{l}\text { Nephrotic syndrome with mild U.R.I. } \\
\text { Completely well with normal urine } 8 \text { mo. later, followed for } 6 y ., \text { well. }\end{array}$ \\
\hline 43 & $\begin{array}{l}3 \text { wks. } \\
7 \text { mo. }\end{array}$ & $\begin{array}{l}\text { Severe nephrotic syndrome, just got over U.R.I. and otitis. Sed. r. }+3 \text {. S.A. calculated from } \\
\text { lowest weight reached after diuresis } 2 \text { wks. later }(28 \text { lbs.). } \\
\text { S.A. correction based on lowest weight ever reached in hospital ( } 6 \text { mo. previously) : based } \\
\text { on present weight (which is } 36 \text { per cent higher), all figures would be } 2.3 \text { per cent lower. Lowest } \\
\text { wt. still included edema. } \\
\text { Just got over severe pneumococcus septicemia with meningitis and peritonitis. Treated } \\
\text { with penicillin. After being almost moribund, he had marked diuresis and improvement. } \\
\text { Subsequently albuminuria ceased and child appeared completely well. Well at } 6 \text { y. of age. }\end{array}$ \\
\hline 44 & $\begin{array}{l}\text { age } 4.0 \\
\text { age } 4.2\end{array}$ & $\begin{array}{l}\text { Mild nephrotic episode following U.R.I. } \\
\text { Clinically well } 3 \text { mo. later. Three years later normal blood chemistry, except alb. } 5.1 \text {, glob. } \\
4.0 \text {. }\end{array}$ \\
\hline 45 & $\begin{array}{l}15 \text { mo. } \\
21 \text { mo. } \\
\text { 2nd test } \\
21 \text { mo. } \\
\text { 3rd test }\end{array}$ & $\begin{array}{l}\text { Patient had marked nephrotic syndrome (Edema }+++ \text {, T.P. } 3.7 \text {, alb. } 1.1) 2 \text { wks. before } \\
\text { this test, then rapidly cleared. Mild U.R.I. at onset. Sed. r. 59-27. } \\
\text { Regular diet. Asymptomatic. Sed. r. } 8 \text {. } \\
\text { High protein diet ( } 3 \mathrm{Gm} \text {. per Kg.). Patient remained completely well for } 14 \text { to } 20 \text { months, } \\
\text { then moved out of town. Last chemistries, including cholesterol, normal. }\end{array}$ \\
\hline
\end{tabular}

\section{ACKNOWLEIGM ENTS}

We should like to express our thanks to Doctors David H. Weintraub, William J. Orr, and A. Wilmot Jacobsen for permitting us to use their private patients in this study.

\section{REFERENCES}

1. Farr, L. E., The effect of dietary protein on the urea clearance of children with nephrosis. J. Clin. Invest., 1936, 15, 703.

2. Emerson, K., Jr., Futcher, P. H., and Farr, L. E., The relation of high and low urea clearances to the inulin and creatinine clearances in children with the nephrotic syndrome. J. Clin. Invest., 1941, 20, 361 .

3. Emerson, K., Jr., and Dole, V. P., Diodrast and inulin clearances in nephrotic children with supernormal urea clearances. J. Clin. Invest., 1943. 22, 447.

4. Galán, E., Nephrosis in children. Observations on eighty-four patients. II. Clearance and saturation tests. Am. J. Dis. Child., 1949, 77, 328.

5. Barnett, H. L., Forman, C. W., McNamara, H., McCrory, W. W., Rapoport, M., Michie, A. J., and Barbero, G., The effect of adrenocorticotropic hor- mone on children with the nephrotic syndrome. II. Physiologic observations on discrete kidney functions and plasma volume. J. Clin. Invest., 1951, 30, 227.

6. Metcoff, J., Kelsey, W. M., and Janeway, C. A., The nephrotic syndrome in children. An interpretation of its clinical, biochemical, and renal hemodynamic features as variations of a single type of nephron disease. J. Clin. Invest., 1951, 30, 471.

7. Earle, D. P., Jr., Taggart, J. V., and Shannon, J. A., Glomerulonephritis. A survey of the functional organization of the kidney in various stages of diffuse glomerulonephritis. J. Clin. Invest., 1944, 23. 119.

8. Bradley, S. E., Bradley, (i. P., Tyson, C. J., Curry, J. J., and Blake, W. D., Renal function in renal diseases. Am. J. Med., 1950, 9, 766.

9. Smith, H. W., Finkelstein, N., Aliminosa, L., Crawford, B., and Graber, M.. The renal clearances of substituted hippuric acid derivatives and other aromatic acids in $\log$ and man. J. Clin. Invest., 1945, 24, 388.

10. Rubin, M. I., Bruck, E., and Rapoport, M., Maturation of renal function in childhood: Clearance studies. J. Clin. Invest., 1949. 28, 1144. 
11. Oliver, J., Architecture of the Kidney in Chronic Bright's Disease. New York and London, Paul B. Hoeber, Inc., 1939.

12. Smith, H. W., The Kidney. Structure and Function in Health and Disease. New York, Oxford Univ. Press, 1951.

13. Personal observation, unpublished.

14. Welsh, C. A., Wellen, I., and Taylor, H. C., Jr., Changes in renal function accompanying the hypertrophy of the remaining kidney after unilateral nephrectomy. J. Clin. Invest., 1944, 23, 750.

15. Bruck, E., Urea Clearance Studies. Presented at Symposium on Renal Function in Infants and Children. Eighth M \& R Pediatric Research Conference, March 2, 1953.

16. Barness, L. A., Moll, G. H., and Janeway, C. H., Nephrotic syndrome. I. Natural history of the disease. Pediatrics, 1950, 5, 486.

17. Berger, E. Y., Farber, S. J., and Earle, D. P., Jr., Renal excretion of mannitol. Proc. Soc. Exper. Biol. \& Med., 1947, 66, 62.
18. Schwartz, I. L., Breed, E. S., and Maxwell, M. H., Comparison of the volume of distribution, renal and extrarenal clearances of inulin and mannitol in man. J. Clin. Invest., 1950, 29, 517.

19. Hubbard, R. S., and Loomis, T. A., The determination of inulin. J. Biol. Chem., 1942, 145, 641.

20. Harrison, H. E., A modification of the diphenylamine method for determination of inulin. Proc. Soc. Exper. Biol. \& Med., 1942, 49, 111.

21. Brun, C., Hilden, T., and Raaschou, F., Physiology of the diseased kidney. Determinations of glomerular filtration, renal blood flow, and maximal tubular excretory capacity and their contribution to an understanding of the function of the diseased kidney. Acta med. Scandinav., 1949, Suppl. 234, 136, 71.

22. Cargill, W. H., The measurement of glomerular and tubular plasma flow in the normal and diseased human kidney. J. Clin. Invest., 1949, 28, 533.

23. Baldwin, D. S., Schreiner, G. E., Breed, E. S., Wesson, L. G., Jr., and Maxwell, M. H., Depression of apparent p-aminohippurate extraction ratio by glucose. J. Clin. Invest., 1950, 29, 614. 